\title{
The benthic marine algae of the tropical and subtropical Western Atlantic: changes in our understanding in the last half century
}

\author{
Michael J. Wynne ${ }^{1, *}$ \\ ${ }^{1}$ University of Michigan Herbarium, 3600 Varsity Drive, Ann Arbor, MI 48109, USA
}

Taylor's (1960) floristic treatment of the benthic marine algae of the tropical and subtropical western Atlantic and Wynne's (2011) "checklist: third revision" serve as benchmarks in a review of changes made in the past half-century period. There has been a great increase in the number of recognized taxa of red, brown and green algae at all taxonomic ranks: from 758 to 1,393 species, an increase of $84 \%$; from 231 to 406 genera, an increase of $75 \%$; and from 63 to 106 families, an increase of $68 \%$. In regard to recognized infraspecific taxa, the increase was less dramatic, from 140 to 185 , thus a $32 \%$ change in the 50 -year period. This review addresses the question: What factors were responsible for this proliferation of taxa that are now recognized in this domain of the tropical and subtropical western Atlantic? The answer is that many reasons contributed to these changes. Foremost among these causes have been the advances in gene-sequencing technologies. Revised phylogenetic relationships have led to many genera being divided into more than one genus, as well as new families and orders being delineated. Numerous examples of cryptic species have been discovered by gene-sequence and DNA-bar coding studies. This trend is depicted by case studies. Examples of genera being divided are Galaxaura, Liagora and Laurencia. Tricleocarpa and Dichotomaria have been segregated from Galaxaura. Trichogloeopsis, Ganonema, Izziella, Yamadaella, and Titanophycus have been segregated from Liagora. Chondrophycus, Osmundea, Palisada, and Yuzurura have been segregated from Laurencia. Examples are given of other genera present in this region of the western Atlantic that have been split up. Many genera have increased in terms of the number of species now assigned to them. Taylor's (1960) treatment recognized only two species in Hypoglossum, whereas Wynne's (2011) checklist contained a total of 9 species of Hypoglossum. Taylor's account included only two species of Botryocladia, but this number had grown to 15 in Wynne's checklist. Examples of new genera and species occurring in the region of the western Atlantic are given, and examples of taxa being newly reported for this domain are provided. An increase in the number of phycologists in Latin and South America, exploration of previously unexplored regions, and the increasing use of SCUBA for collecting and at greater depths have all contributed to the increase in the number of algal taxa that are now recognized as occurring in the tropical and subtropical western Atlantic.

Key Words: historical treatment; long-term changes; marine algae; tropical and subtropical western Atlantic

The volume "Marine algae of the eastern tropical and subtropical coasts of the Americas" produced by W. R. Taylor in 1960 was a comprehensive treatment of the benthic seaweeds of this region and remains a useful compendium for the breadth of its coverage, its detailed descriptions, and excellent artwork. But in the 50 years since that floristic treatment, numerous regional treatments have appeared, many new taxa described, and many new records have been published. Wynne has produced several checklists over the years $(1986,1998,2005)$ in efforts to gather the pertinent literature from

(c) This is an Open Access article distributed under the terms of the Creative Commons Attribution Non-Commercial License (http://creativecommons.org/licenses/by-nc/3.0/) which permits unrestricted non-commercial use, distribution, and reproduction in any medium, provided the original work is properly cited.
Received 1 April 2011, Accepted 2 May 2011

*Corresponding Author

E-mail: mwynne@umich.edu

Tel: +1-734-764-8415, Fax: +1-734-998-0038 
this broad region from Cape Hatteras, North Carolina, in the north to southern Brazil in the south. The recently published third revision of this checklist (Wynne 2011) gives us the opportunity to see the dramatic changes in the schemes of classification and in the treatment of genera of red, brown, and green algae from the new information provided by the flood of phylogenetic data. This paper reviews important changes with specific and more general examples.

Table 1 provides a comparison of the numbers of taxa (families, genera, species, and infraspecific taxa) of red, brown, and green algae in Taylor (1960) and in Wynne (2011), giving the total numbers in each category and also showing the percent increases between these two chosen benchmarks.

Table 1. A comparison of the numbers of taxa (families, genera, species, and infraspecific taxa) of red, brown, and green algae in Taylor (1960) and in Wynne (2011)

\begin{tabular}{|c|c|c|c|c|c|c|c|c|}
\hline & \multicolumn{2}{|c|}{ Family } & \multicolumn{2}{|c|}{ Genus } & \multicolumn{2}{|c|}{ Species } & \multicolumn{2}{|c|}{ Infraspecific taxa } \\
\hline & $\begin{array}{l}\text { Taylor } \\
\text { (1960) }\end{array}$ & $\begin{array}{l}\text { Wynne } \\
\text { (2011) }\end{array}$ & $\begin{array}{l}\text { Taylor } \\
\text { (1960) }\end{array}$ & $\begin{array}{l}\text { Wynne } \\
\text { (2011) }\end{array}$ & $\begin{array}{l}\text { Taylor } \\
(1960)\end{array}$ & $\begin{array}{l}\text { Wynne } \\
\text { (2011) }\end{array}$ & $\begin{array}{l}\text { Taylor } \\
(1960)\end{array}$ & $\begin{array}{l}\text { Wynne } \\
(2011)\end{array}$ \\
\hline Rhodophyta & 31 & 58 & 133 & 255 & 454 & 905 & 44 & 55 \\
\hline Heterokontophyta & 15 & 18 & 45 & 76 & 101 & 175 & 15 & 33 \\
\hline Chlorophyta & 17 & 30 & 53 & 75 & 203 & 313 & 81 & 97 \\
\hline Total & 63 & 106 & 231 & 406 & 758 & 1,393 & 140 & 185 \\
\hline Increase (\%) & & 68 & & 75 & & 84 & & 32 \\
\hline
\end{tabular}

This review addresses the question of what factors were responsible for the significant increases in the percentages of taxa recognized in the past half century for the marine algal flora of the western Atlantic. The fact is that many reasons have played a role in the expansion of our knowledge. The technology of gene-sequencing and the employment of those data to understand phylogenetic relationships have been foremost among the causes for the increase in the number of taxa at all levels. New information has resulted in broad realignments with respect to how the orders and classes of these groups are interrelated. Many red algal orders have been delineated since the time of Taylor's (1960) floristic treatment, especially among the subclass Bangiophycidae. Only seven orders of red algae were recognized in Taylor's (1960) treatment, and those orders were assigned to a single class (Rhodophyceae) with two sub-classes (Bangioideae and Florideae). In Wynne's (2011) treatment the red algae are assigned to six classes, and the Florideophyceae, the largest class, contains 21 orders at the present time. The most species-rich order, the Ceramiales, is no longer considered necessarily to be the most derived (Yoon et al. 2006, Le Gall and Saunders 2007, Maggs et al. 2007), and the former broadly defined family Ceramiaceae has been split up into four families in this checklist (Choi et al. 2008).

On the other hand, molecular-based evidence has resulted in the amalgamation of many families of brown algae into a broadly circumscribed Chordariaceae (Peters and Ramírez 2001) and several orders of brown algae (Chordariaes, Dictyosiphonales, and Scytosiphonales) into a broadly circumscribed order Ectocarpales (Draisma et al. 2003, Cho et al. 2004). Likewise, radically different views of how brown algal orders are interrelated have been proposed, again due to recent molecular studies, and the Laminariales and Fucales are no longer placed in the more derived positions in the evolutionary scheme (Draisma et al. 2001, Rousseau et al. 2001, Cho et al. 2004, Kawai et al. 2007, Reviers et al. 2007, Phillips et al. 2008). Higher-level rearrangements in the green algae reflect the results of recent molecular-based phylogenetic analyses (Lam and Zechman 2006, Pröschold and Leliaert 2007, Curtis et al. 2008, Zechman et al. 2010).

More exacting methods and closer scrutiny, often making use of molecular-sequencing technologies, have led to the recognition that some genera are best divided into more than one genus. These revised arrangements better reflect more accurate phylogenetic relationships. This trend over the past half century is demonstrated with the examples of the genera Galaxaura, Liagora, and Laurencia.

Changes in our concept of Galaxaura over the past 50 years:

\begin{tabular}{|c|c|c|c|c|}
\hline Taylor (1960) & Wynne (1986) & Wynne (1998) & Wynne (2005) & Wynne (2011) \\
\hline Galaxaura & Galaxaura & Galaxaura & Galaxaura & Galaxaura \\
\hline \multirow[t]{5}{*}{14 spp. } & 6 spp. & 5 spp. & 2 spp. & 2 spp. \\
\hline & & Tricleocarpa & Tricleocarpa & Tricleocarpa \\
\hline & & 2 spp. & 2 spp. & 2 spp. \\
\hline & & & Dichotomaria & Dichotomaria \\
\hline & & & 2 spp. & 2 spp. \\
\hline
\end{tabular}


Taylor (1960) referred to the fact then known in a preliminary way that some of the taxa of Galaxaura were "species pairs" representing dimorphic gametophytic and sporophytic phases of the same species. Howe (1917) had earlier recognized that in the West Indian G. obtusata the gametophytes and tetrasporophytes are markedly different in the structure of their cortex, such that they would fall into two different species on the basis of Kjellman's (1900) monograph of the genus. The reduction of the relatively large number (14) species of Galaxaura recognized by Taylor (1960) to only 6 species in Wynne (1986) was a reflection of the monographic treatment by Papenfuss et al. (1982). Dimorphic gametophytic and sporophytic stages in Galaxaura rugosa (J. Ellis et Sol.) J. V. Lamour. (Figs 1 \& 2) were recognized by Littler and Littler (2000). The next major change in the circumscription of Galaxaura was made by Huisman and Borowitzka (1990), who separated off some species into the new segregate genus Tricleocarpa based on morphological, reproductive, and life history differences. Species of Tricleocarpa, including T. cylindrica (J. Ellis et Sol.) Huisman \& Borow. (Fig. 3) and T. fragilis (L.) Huisman \& R. A. Townsend (Fig. 4), were distinguished by a life history showing an alternation of heteromorphic phases, involving a microscopic filamentous tetrasporophyte alternating with a dominant gametophytic phase, in contrast to the alternation of isomorphic phases expressed in Galaxaura sensu stricto. Later, Huisman et al. (2004b) offered evidence for the reinstatement of the genus Dichotomaria Lamarck, lectotypified with D. marginata (J. Ellis et Sol.) Lam. (Fig. 5), and for the transfer of some species of Galaxaura into that reinstated genus. Recognition of Dichotomaria avoided a situation in which Galaxaura would be para / polyphyletic based on the gene-sequence results. A second species now recognized as assigned to Dichotomaria is D. obtusata (J. Ellis et Sol.) Lam. (Fig. 6).

Changes in our concept of Liagora over the past 50 years:

$\begin{array}{lllll}\text { Taylor (1960) } & \text { Wynne (1986) } & \text { Wynne (1998) } & \text { Wynne (2005) } & \text { Wynne (2011) } \\ \text { Liagora } & \text { Liagora } & \text { Liagora } & \text { Liagora } & \text { Liagora } \\ 9 \mathrm{spp} . & \text { 11 spp. } & 9 \mathrm{spp} . & 5 \mathrm{spp} . & 4 \mathrm{spp} . \\ & \text { Trichogloeopsis } & \text { Trichogloeopsis } & \text { Trichogloeopsis } & \text { Trichogloeopsis } \\ & 1 \mathrm{sp} . & 1 \mathrm{sp} . & 1 \mathrm{sp} . & 1 \mathrm{sp} . \\ & \text { Ganonema } & \text { Ganonema } & \text { Ganonema } \\ & 1 \mathrm{sp} . & 5 \mathrm{sp} . & 6 \mathrm{sp} . \\ & & \text { Izziella } & \text { Izziella } \\ & & 1 \mathrm{sp} . & 1 \mathrm{sp} . \\ & & \text { Yamadaella } & \text { Yamadaella } \\ & & 1 \mathrm{sp} . & 1 \mathrm{sp} . \\ & & & \text { Ttanophycus } \\ & & & 1 \text { sp. }\end{array}$

A total of nine species of Liagora were recognized by Taylor (1960), including L. ceranoides J. V. Lamour. (Fig. 7). The first move to break Liagora into a number of the genera now recognized was made by Abbott and Doty (1960), who recognized the segregate genus Trichogloeopsis distinguished by its possession of sterile rhizoids produced by the gonimoblast and by the fact that the carpogonial branch was a modified vegetative filament, in contrast to the accessory (specialized) carpogonial branch in Liagora sensu stricto. Trichogloeopsis was typified by T. hawaiiana and also included T. pedicellata (M. Howe) I. A. Abbott et Doty (Fig. 8). Although the segregate genus Ganonema was established by Fan and Wang (1974), at first Abbott (1984) offered arguments to merge it back within Liagora. But Huisman and Kraft (1994) subsequently presented persuasive evidence for the recognition of Ganonema with an emended definition. Although the generitype Ganonema farinosum (J. V. Lamour.) K. C. Fan et Yung C. Wang (Fig. 9) was the only species recognized as occurring in the western Atlantic by Wynne (1998), four other species have been assigned to the genus by Wynne's (2005) second revision: G. dendroideum (P. Crouan et H. Crouan) D. L. Ballant. et Aponte (Ballantine and Aponte 2002b) (Fig. 10), G. megagynum (Børgesen) Huisman and G. pinnatum (Harv.) Huisman (both transfers made by Huisman 2002), and G. norrisiae (I. A. Abbott) Huisman, I. A. Abbott et A. R. Sherwood (Huisman et al. 2004a). A new species of Ganonema, G. vermiculare, was described from Puerto Rico by Ballantine and Abbott (2006).

The genus Izziella was established by Doty (1978). Abbott (1990), however, offered reasons to merge the genus within Liagora and treated the type species of Izziella, I. abbottiae Doty, as conspecific with L. orientalis J. Agardh. She reported the presence of L. orientalis from Puerto Rico and Colombia. Later, Huisman and Schils (2002) recognized notable dif- 
ferences in the type species of Izziella from L. viscida (Forsskål) C. Agardh, the generitype of Liagora, and thus reinstated Izziella. Yamadaella was segregated from Liagora by Abbott (1970), with the single species, Y. caenomyce (Decne.) I. A. Abbott (Fig. 11), and the genus remains monotypic. Although the genus was known from many records throughout the tropical Indo-Pacific, its first report to occur in the western Atlantic was made by Wynne and Huisman (1998) with a collection from the Dominican Republic. Liagora valida Harv., with a type locality of Sand Key, Florida, USA, was separated into its own genus, Titanophycus, by Huisman et al. (2006) on the basis of gene-sequence evidence. At this time the genus remains monotypic, with T. validus (Harv.) Huisman, G. W. Saunders et A. R. Sherwood (Fig. 12).

Changes in our concept of the genus Laurencia over the past 50 years:

\begin{tabular}{|c|c|c|c|c|}
\hline Taylor (1960) & Wynne (1986) & Wynne (1998) & Wynne (2005) & Wynne (2011) \\
\hline Laurencia & Laurencia & Laurencia & Laurencia & Laurencia \\
\hline \multirow[t]{9}{*}{11 spp. } & 22 spp. & 32 spp. & 23 spp. & 24 spp. \\
\hline & & & Chondrophycus & Chondrophycus \\
\hline & & & $9 \mathrm{sp}$. & $1 \mathrm{sp}$. \\
\hline & & & Osmundea & Osmundea \\
\hline & & & $3 \mathrm{sp}$. & $4 \mathrm{sp}$. \\
\hline & & & & Palisada \\
\hline & & & & 5 spp. \\
\hline & & & & Yuzurura \\
\hline & & & & 1 sp. \\
\hline
\end{tabular}

The subdivision of Laurencia sensu lato into several segregate genera began with the proposal of Nam et al. (1994) to reinstate Osmundea Stackhouse (1809), with O. pinnatifida (Hudson) Stackhouse as generitype. This was followed by the proposal made by Garbary and Harper (1998) for the elevation of subgenus Chondrophycus of Tokida and Saito (Saito 1967) to generic status. Wynne's (2005) treatment recognized 3 species of Osmundea and 9 species of Chondrophycus. Later, Abe et al. (2006) and others had shown with molecular phylogenetic evidence that the species recognized within Chondrophycus formed two separate clades. Nam (2006) offered both morphological and molecular evidence evidence to recognize the segregate genus Palisada at the generic level. Nam's initial proposal to recognize Palisada as a segregate genus was invalid as were his proposed transfers of many species to that genus. Subsequently, Nam (2007) satisfied the requirements of the International Code of Botanical Nomenclature. Martin-Lescanne offered evidence to elevate Nam's (1999) subgenus Yuzurua, with the single species Y. poiteaui (J. V. Lamour.) Martin-Lescanne, to the generic level, segregated from Palisada on both molecular and morphological evidence (Martin-Lescanne et al. 2010).

The following species have been attributed to Laurencia sensu stricto in the flora of the western Atlantic post-1960: L. aldingensis Saito et Womersley (Carvalho et al. 2003), L. caduciramulosa Masuda et Kawaguchi (Cassano et al. 2006, Sentíes et al. 2010), L. catarinensis Cord. -Mar. et Fujii (1985), L. coelenterata D. L. Ballantine et Aponte (1995), L. decumbens Kütz. (Oliveira and Ugadim 1974, Rodríguez de Rios and Lobo 1984, both as L. pygmaea), L. epiphylla Boisset et Lino (Areces et al. 2003), L. foldatsii (Rodríguez de Rios 1981), L. hancockii E. Y. Dawson (Huerta and Garza 1980), L. marilzae Gil-Rodriguez et al. (Rocha-Jorge et al. 2010, Sentíes et al. 2011), L. minuscula (Schnetter 1975), L. oliveirana (Yoneshigue 1985), L. translucida Fujii et Cord. -Mar. (1996), and L. venusta Yamada (Sentíes et al. 2001, Fujii et al. 2005). The name $L$. scoparia J. Agardh, which had been listed in Taylor (1960), has been replaced in Wynne (2011) by L. dendroidea J. Agardh, the older taxonomic synonym. Fujii et al. (2006) used $r b c$ L sequence data to show that Brazilian specimens going under the names L. scoparia, L. arbuscula, and L. filiformis do not show significant genetic variation. They concluded that these taxa likely represent a single morphologically variable species in Brazil. Cassano (2009) eliminated the Australian-based L. filiformis (C. Agardh) Mont. from the Brazilian flora. The presence of L. brongniartii in the flora was confirmed by Saito and Womersley (1974). Silva (1972) proposed the name L. caraibica to replace the illegitimate name L. nana M. Howe.

Chondrophycus furcatus (Cord. -Mar. et M. T. Fujii) M. T. Fujii et Senties is the only species currently assigned to that genus for the western Atlantic (Fujii and Sentíes 2005). Four species of Osmundea are at present recognized as occurring in the western Atlantic: O. lata (M. Howe et W. R. Taylor) Yonesh., M. T. Fujii et Gurgel (Yoneshigue-Valentin et al. 2003), O. oederi (Gunnerus) G. Furnari in Serio et al. (2008), O. pinnatifida (Huds.) Stackh., and O. sinicola (Setch. et N. L. Gardner) K. W. Nam (in Nam et al. 1994) (Dawson 1962). Serio et al. (2008) proposed treating Laurencia bolivarii Rodríguez de Rios (1981) as conspecific with O. oederi. 

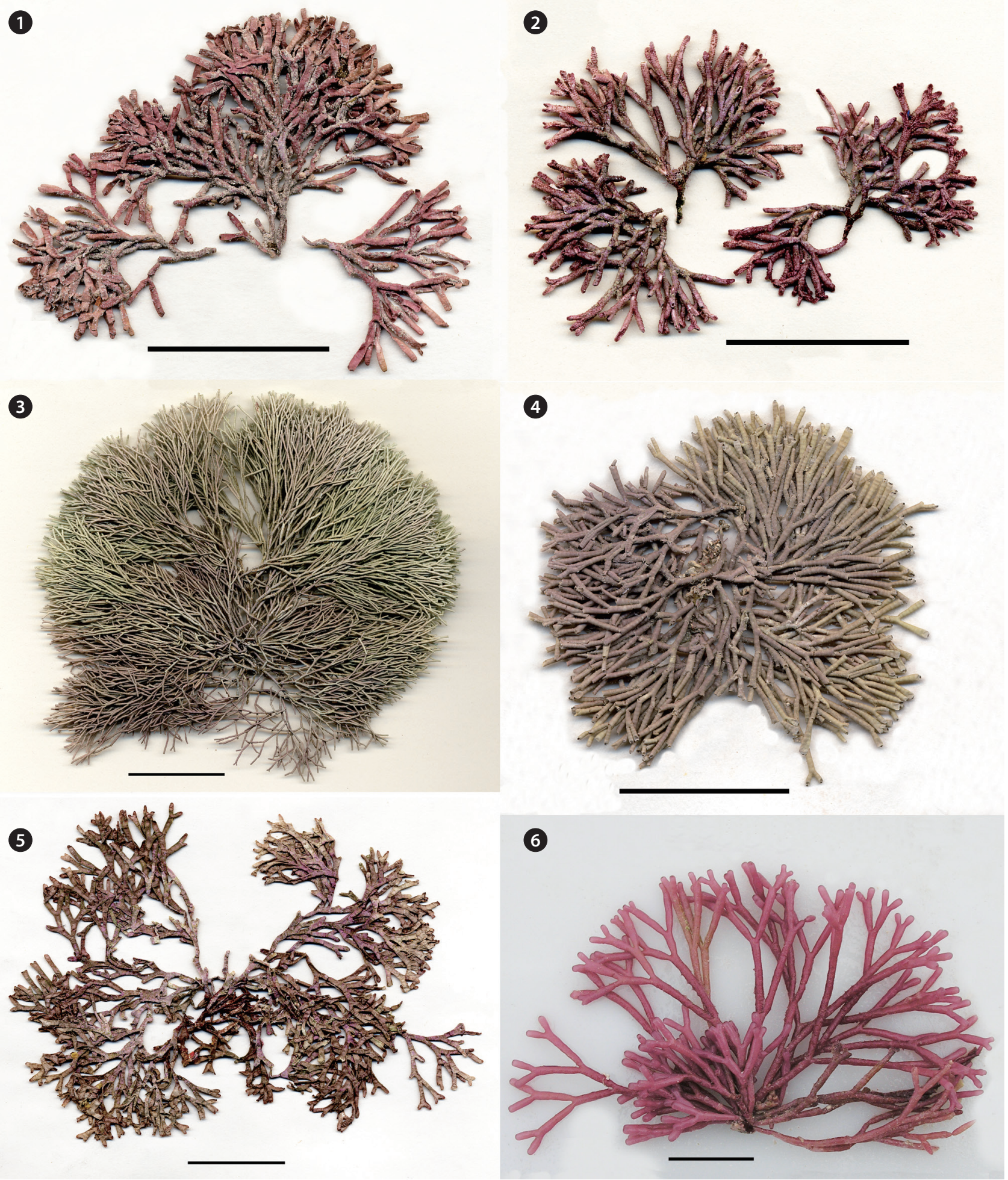

Figs 1-6. Fig. 1. Galaxaura rugosa. Gametophytic plant. [Guadeloupe, M. Wynne 8245]. Fig. 2. G. rugosa. Tetrasporophytic plant. [Guadeloupe, M. Wynne 8308]. Fig. 3. Tricleocarpa cylindrica. [Dominican Republic, M. Wynne 9900]. Fig. 4. T. fragilis. [St. Kitts, M. Wynne 10501$]$. Fig. 5. Dichotomaria marginata. [Guadeloupe, M. Wynne 8138]. Fig. 6. D. obtusata. [Bermuda, C. Schneider \& C. Lane 09-34-19]. Scale bars represent: Figs $1-6,3 \mathrm{~cm}$. 

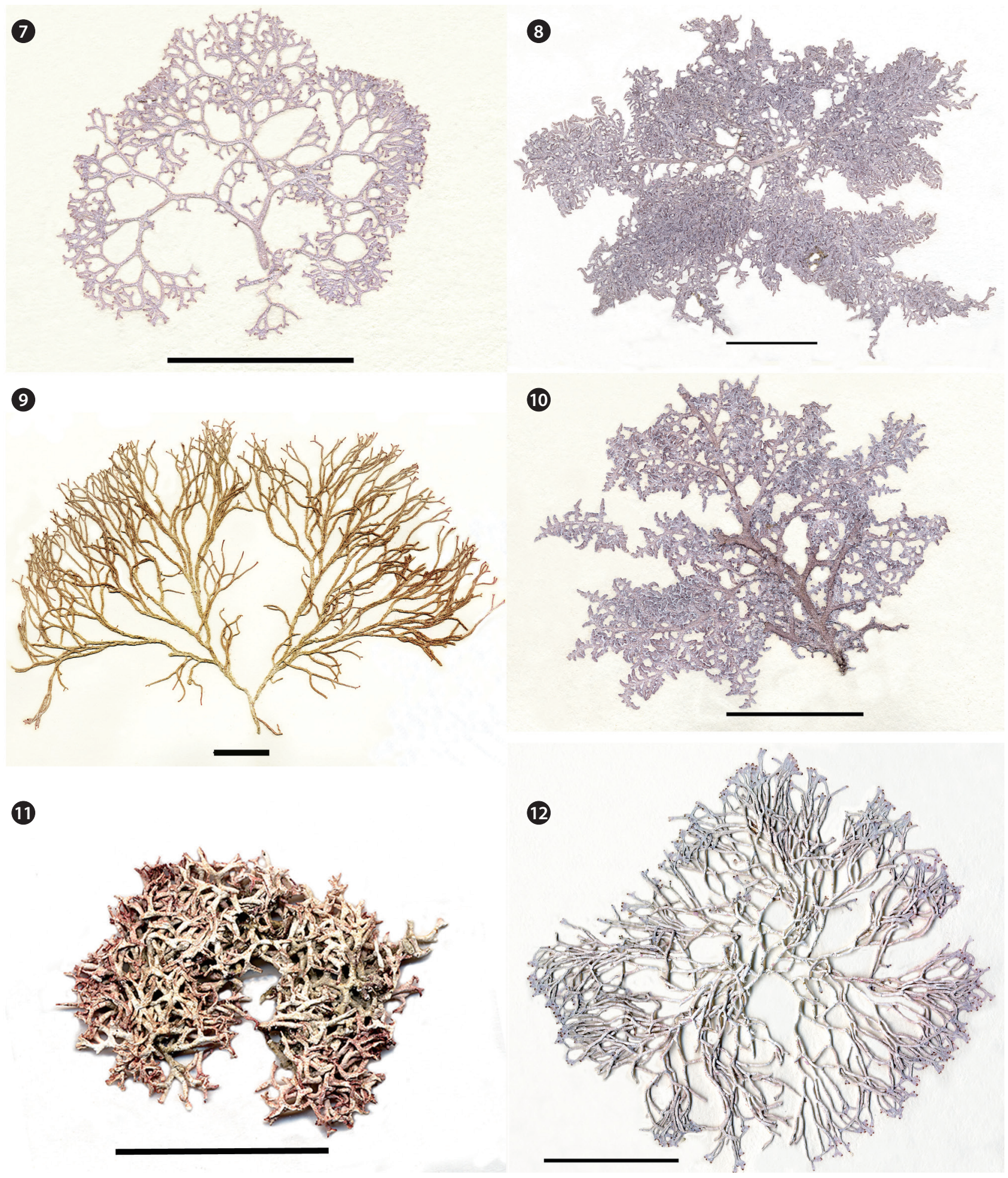

Figs 7-12. Fig. 7. Liagora ceranoides. [Bahamas, M. Wynne 11084]. Fig. 8. Trichogloeopsis pedicellata. [Puerto Rico, M. Wynne 11063 ]. Fig. 9. Ganonema farinosum. [Puerto Rico, M. Wynne 10982]. Fig. 10. G. dendroideum. [Bahamas, M. Wynne 11700]. Fig. 11. Yamadaella caenomyce. [Dominican Republic, M. Wynne 9846]. Fig. 12. Titanophycus validus. [Puerto Rico, M. Wynne 11059]. Scale bars represent: Figs 7-12, 3 cm. 
Five species are currently assigned to Palisada for the western Atlantic: P. corallopsis (Mont.) Sentíes, M. T. Fujii et Díaz (Sentíes and Díaz-Larrea 2008), P. flagllifera (J. Agardh) K. W. Nam (Cordeiro-Marino 1978, Nam 2007), P. intermedia (Yamada) K. W. Nam (Rodríguez de Rios and Saito 1982, Nam 2007), P. iridescens (M. J. Wynne et D. L. Ballant.) K. W. Nam (Wynne and Ballantine 1991, Nam 2007) (Figs 41-43), and O. perforata (Bory) K. W. Nam (Nam 2007). Evidence has been presented by Cassano et al. (2009) to treat Palisada [Laurencia] papillosa as a taxonomic synonym of P. perforata. Yuzurua is a monotypic genus (Martin-Lescanne et al. 2010), and Y. poiteaui contains the var. gemmifera (Harv.) M. J. Wynne (2011) based on the evidence presented by Díaz-Larrea et al. (2007) to treat Chondrophycus gemmiferus as a variety within C. poiteaui.

Other examples of the recognition of segregated genera and reference(s):

Neosiphonia out of Polysiphonia

Parviphycus out of Gelidiella

Prerocladiella out of Pterocladia

Asteromenia out of Fauchea

Gayliella out of Ceramium

Tiffaniella out of Spermothamnion

Frikkiella out of Branchioglossum

Hydropuntia out of Gracilaria

Canistrocarpus out of Dictyota

Feldmannia out of Ectocarpus

Asteronema out of Ectocarpus

Neoralfsia out of Ralfsia

Asterocladon out of Ectocarpus

Gayralia out of Monostroma

Blidingia out of Enteromorpha/Ulva

Pedobesia out of Derbesia

Phyllodictyon out of Struvea

Caulerpella out of Caulerpa

Parvocaulis out of Acetabularia
(Kim and Lee 1999, Guimarães et al. 2004)

(Santelices 2004)

(Santelices and Hommersand 1997)

(Huisman and Millar 1996, Saunders et al. 2006)

(Cho et al. 2008)

(Doty and Meñez 1960)

(Wynne and Schneider 1996)

(Wynne 1989, Gurgel and Fredericq 2004)

(De Clerck et al. 2006)

(Hamel 1939, Knoepffler-Péguy 1970)

(Delépine and Asensi 1975)

(Lim et al. 2007)

(Müller et al. 1999)

(Vinogradova 1969)

(Kylin 1947)

(MacRaild and Womersley 1974, Wynne and Leliaert 2001)

(Kraft and Wynne 1996)

(Prud'homme van Reine and Lokhorst 1992, Famà et al. 2002)

(Berger et al. 2003)

The above examples of the splitting up of genera and also the recognition of cryptic species accounts for the increase in number of taxa. But the merger of genera is another reality, with such examples:

Pseudogloiophloea into Scinaia

Gelidiopsis into Ceratodictyon

Dilophus into Dictyota

Enteromorpha into Ulva

Cystodictyon into Anadyomene

Acicularia into Acetabularia
(Huisman 1985)

(Norris 1987, Le Gall et al. 2008)

(Hörnig et al. 1992)

(Hayden et al. 2003)

(Littler and Littler 1991)

(Bailey et al. 1976)

There are multiple reasons for the great increase in the number of species in known genera. One obvious explanation has been the exploration in areas that had not been previously explored and also the greater utilization of SCUBA and at greater depths. The number of practicing phycologists has greatly increased, especially in Cuba, Mexico, Colombia, Venezuela, and Brazil. The routine employment of gene-sequencing methods and DNA bar-coding has frequently resulted in the appreciation of "cryptic species," whereby what might have been thought to be a single often widespread species proved to be composed of multiple species, some of which might be undescribed while in other cases names that had been thought to be taxonomic synonyms might have to be reinstated. This has happened with such species as Centroceras clavulatum (Won et al. 2009) and Gracilaria tikvahiae (Gurgel et al. 2004c) and in such genera as Codium (Verbruggen et al. 2007a). Kooistra and Verbruggen (2005) recognized the existence of "species pairs" in certain species of Halimeda such that Atlantic and Pacific sibling species could be recognized. 
Examples of the increase in the number of species recognition in selected genera: Species of Hypoglossum recognized in the western Atlantic for the past 50 years:

$\begin{array}{lllll}\text { Taylor (1960) } & \text { Wynne (1986) } & \text { Wynne (1998) } & \text { Wynne (2005) } & \text { Wynne (2011) } \\ \text { H. involvens } & \text { H. involvens } & \text { H. involvens } & \text { H. involvens } & \text { H. involvens } \\ \text { H. tenuifolium } & \text { H. tenuifolium } & \text { H. tenuifolium } & \text { H. tenuifolium } & \text { H. tenuifolium } \\ & \text { H. anomalum } & \text { H. anomalum } & \text { H. anomalum } & \text { H. anomalum } \\ & \text { H. hypoglossoides } & \text { H. hypoglossoides } & \text { H. hypoglossoides } & \text { H. hypoglossoides } \\ & \text { H. caloglossoides } & \text { H. caloglossoides } & \text { H. caloglossoides } \\ & \text { H. rhizophorum } & \text { H. rhizophorum } & \text { H. rhizophorum } \\ & \text { H. simulans } & \text { H. simulans } & \text { H. simulans } \\ & \text { H. subsimplex } & \text { H. subsimplex } & \text { H. subsimplex }\end{array}$

The tally of species of Hypoglossum recognized as present in the western Atlantic has grown considerably since the two species included in Taylor's (1960) treatment, H. involvens and H. tenuifolum (Figs 13 \& 15), both described from Key West, Florida, USA, by Harvey (1853). The European-based type of the genus, H. hypoglossoides (Stackhouse) Collins et Herv. (Wynne 1984) has been widely reported in the western Atlantic, including Bermuda (Schneider 2000) (Figs 18-20), Cuba (Martínez-Daranas et al. 2002), Colombia (Díaz-Pulido and Díaz-Ruíz 2003), and Brazil (Horta et al. 2003). Hypoglossum anomalum was described by Wynne and Ballantine (1986) (Figs 14, 16 \& 17), with a type locality of La Parguera, Puerto Rico. It was later recorded from the Bahamas (Ballantine and Aponte 2005), Brazil (Horta and Oliveira 2001), and the Dry Tortugas of Florida (Dawes and Mathieson 2008) as well as Australia and the Indo-Pacific. Although Hypoglossum caloglossoides was described by Wynne and Kraft (1985) from Lord Howe Island in the South Pacific, it was later reported by Bucher et al. (1990) to occur at Molasses Reef, the Florida Keys, USA, and has also been reported from Bermuda (Schneider 2004) (Figs 27 \& 28), the Bahamas (Ballantine and Aponte 2005), and Puerto Rico (Ballantine et al. 2009). Hypoglossum rhizophorum (Fig. 26) was described from La Parguera, Puerto Rico, by Ballantine and Wynne (1988) with later records from Florida (Ballantine 1996), Bermuda (Schneider 2000), and the Bahamas (Ballantine and Aponte 2005). Hypoglossum simulans (Figs 21 \& 22) was described by Wynne et al. (1989) from Guadeloupe, French West Indies, and later from the Bahamas (Ballantine and Aponte 2005). There are many records also from the tropical Indo-Pacific. Hypoglossum subsimplex (Figs 24 \& 25) was described from Content Key in the Florida Keys, USA, by Wynne (1994) and was later reported to occur in the Serrana Bank, southwestern Caribbean off Nicaragua (Díaz-Pulido and Bula-Meyer 1997), Bermuda (Schneider 2000) and Puerto Rico (Ballantine et al. 2002). Finally, Schneider (2000) reported the presence of Hypoglossum barbatum Okamura in Bermuda (Fig. 23). This record represented the first report of this species, originally described from Hyuga, Miyazaki Pref., Japan (Okamura 1901), from the Atlantic Ocean. At the same time Schneider (2000) referred to its possible presence in Florida, although the determination was uncertain.

Species of Botryocladia from the tropical / subtropical western Atlantic recognized in the past $\mathbf{5 0}$ years:

\begin{tabular}{|c|c|c|c|c|}
\hline Taylor (1960) & Wynne (1986) & Wynne (1998) & Wynne (2005) & Wynne (2011) \\
\hline B. occidentalis & B. occidentalis & B. occidentalis & B. occidentalis & B. occidentalis \\
\hline \multirow[t]{14}{*}{ B. pyriformis } & B. pyriformis & B. pyriformis & B. pyriformis & B. pyriformis \\
\hline & B. monoica & B. monoica & B. monoica & B. monoica \\
\hline & B. papenfussiana & B. papenfussiana & B. papenfussiana & B. papenfussiana \\
\hline & B. shanksii & B. shanksii & B. shanksii & B. shanksii \\
\hline & B. spinulifera & B. spinulifera & B. spinulifera & B. spinulifera \\
\hline & B. wynnei & B. wynnei & B. wynnei & B. wynnei \\
\hline & & B. ganesanii & B. ganesanii & B. ganesanii \\
\hline & & & B. bahamense & B. bahamense \\
\hline & & & B. ballantinei & B. ballantinei \\
\hline & & & B. caraibica & B. caraibica \\
\hline & & & & B. bermudana \\
\hline & & & & B. exquisita \\
\hline & & & & B. flookii \\
\hline & & & & B. iridescens \\
\hline
\end{tabular}


Only two species of Botryocladia, B. occidentalis (Børgesen) Kylin and B. pyriformis (Børgesen) Kylin, were recognized as present in the western Atlantic by Taylor (1960). By the time of Wynne's (1986) first checklist, five species had been added to the flora: B. monoica Schnetter (1978) with a type locality near Punta de Betin, Santa Marta, on the Caribbean coast of Colombia; B. papenfussiana Ganesan et Lemus (1972) with a type locality of Peñoncito, Cumaná, Venezuela; $B$. shanksii E. Y. Dawson (1962) with a type locality of Puerto Limon, Atlantic coast of Costa Rica, B. spinulifera W. R. Taylor et I. A. Abbott (1973) (Fig. 29) with a type locality of Grass Point, St. Croix, U.S. Virgin Islands, and B. wynnei D. L. Ballant. (Ballantine 1985) (Fig. 30) with a type locality 5 km offshore La Parguera, Puerto Rico. In the first revision (Wynne 1998) one more species had been added, B. ganesanii Aponte Díaz (1988) with a type locality of Pampatar, Isla de Margarita, Venezuela. Three species were added to the second revision (Wynne 2005): B. bahamensis D. L. Ballant. et Aponte (2002a) with a type locality of Lee Stocking Island, the Bahamas; B. ballantinei Gavio et Fredericq (2005) with a type locality at 60$70 \mathrm{~m}$ depth offshore Louisiana, USA; and B. caraibica Gavio et Fredericq (2003) with a type locality of Bocas del Toro, Isla Colón, Caribbean Panama. Four more species had been described by the time of Wynne's (2011) third revision. Schneider and Lane (2008), using both morphological and molecular analyses, added three newly described species of Botryocladia all from Bermuda: B. bermudana (Fig. 31) with a type locality of Hunt Island, Port Royal Bay; B. equisita (Figs 33 \& 34) with a type locality of Bermuda Aquarium reef tank, Harrington Sound, and B. flookii (Fig. 32) with a type locality of Walsingham Pond, Hamilton Parish. Schneider and Lane (2008) referred to several of these new species, B. bahamense, B. ballantinei, B. bermudana and B. caraibica as member of the Greater Caribbean "B. pyriformis-complex." Modern molecular methods of gene-sequencing are teasing apart these cryptic taxa into distinguishable species. Ballantine and Ruiz (2008) described B. iridescens (Figs 35-37) with a type locality of La Parguera, Puerto Rico.

\section{Examples of newly described taxa post-1960:}

Numerous new genera, based upon types occurring in the tropical and subtropical Western Atlantic, have been described in the past five decades. The following new genera are listed according to their phylum:

Rhodophyta: Augophyllum Lin et al. (2004), Calliclavula Schneider in Searles and Schneider (1989), Calonitophyllum

Aregood (1975), Crassitegula Schneider et al. (2006), Cresia Lozada-Troche et al. (2010), Crouanophycus Athanasiadis (1998), Diplothamnion Joly et Yamaguishi in Joly et al. (1966), Erythrolobus Scott et al. (2006), Frikkiella Wynne et Schneider (1996), Heterodasya Joly et Oliveira (1966), Liagorothamnion Huisman et al. (2001), Nwynea Searles in Searles and Schneider (1989), Pseudobangia Müller et Sheath in Müller et al. (2005), Renouxia Fredericq et Norris (1995), Rhododictyon Taylor (1961), Rhodogorgon Norris et Bucher (1989), Waldoia Taylor (1962b)

Heterokontophyta: Cladophyllum Bula-Meyer (1980), Elachistiella Cassano et al. (2004), Hummia Fiore (1975), Jolyna Guimarães in Guimarães et al. (1986), Onslowia Searles in Searles and Leister (1980), Verosphacela Henry (1987)

Chlorophyta: Pseudoderbesia Calderón et Schnetter (1991), Smithsoniella Sears et Brawley (1982), Verdigellas Ballantine et Norris (1994)

Several genera of red algal parasites have been described, such as Dawsoniocolax Joly et Yamaguishi-Tomita (1967, 1970), Grateloupiocolax Schnetter et al. (1983), Champiocolax Bula-Meyer (1985), Centrocerocolax Joly (1966), Spyridiocolax Joly et Oliveira (1966), Meridiocolax Morrill (1976). The parasitic genus Gelidiocolax, which was not included in Taylor (1960), was added to the flora by the descriptions of G. desikacharyi (Ganesan 1970) and G. pustulata (Yoneshigue and Oliveira 1984). The report of Pterocladiophila in the Caribbean by Stegenga and Vroman (1986) added that parasitic red alga to the flora.

On the other hand, some genera newly described in recent years have been relegated to taxonomic synonymy. Examples are the merger of Johnson-sea-linkia (Eiseman and Earle 1983) into Rhipiliopsis proposed by Norris and Blair (in Norris and Olsen 1991) and the merger of Siphonoclathrus Earle et Young (1972) into Rhipiliopsis proposed by Farghaly and Denizot (1979).

Meristiella was initially segregated from Eucheuma (Cheney in Gabrielson and Cheney 1987), but later its merger into Meristotheca was proposed by Faye et al. (2004).

Mesothamnion (Børgesen 1917), a genus that was recognized by Taylor (1960), was initialy merged within Pleonosporium by Norris (1985) but was later merged within Spongoclonium (Sonder 1855) from the evidence presented by Womersley and Wollaston (1998).

Searlesia was established by Schneider and Eiseman (1979) as a new genus based on Membranoptera subtropica de- 


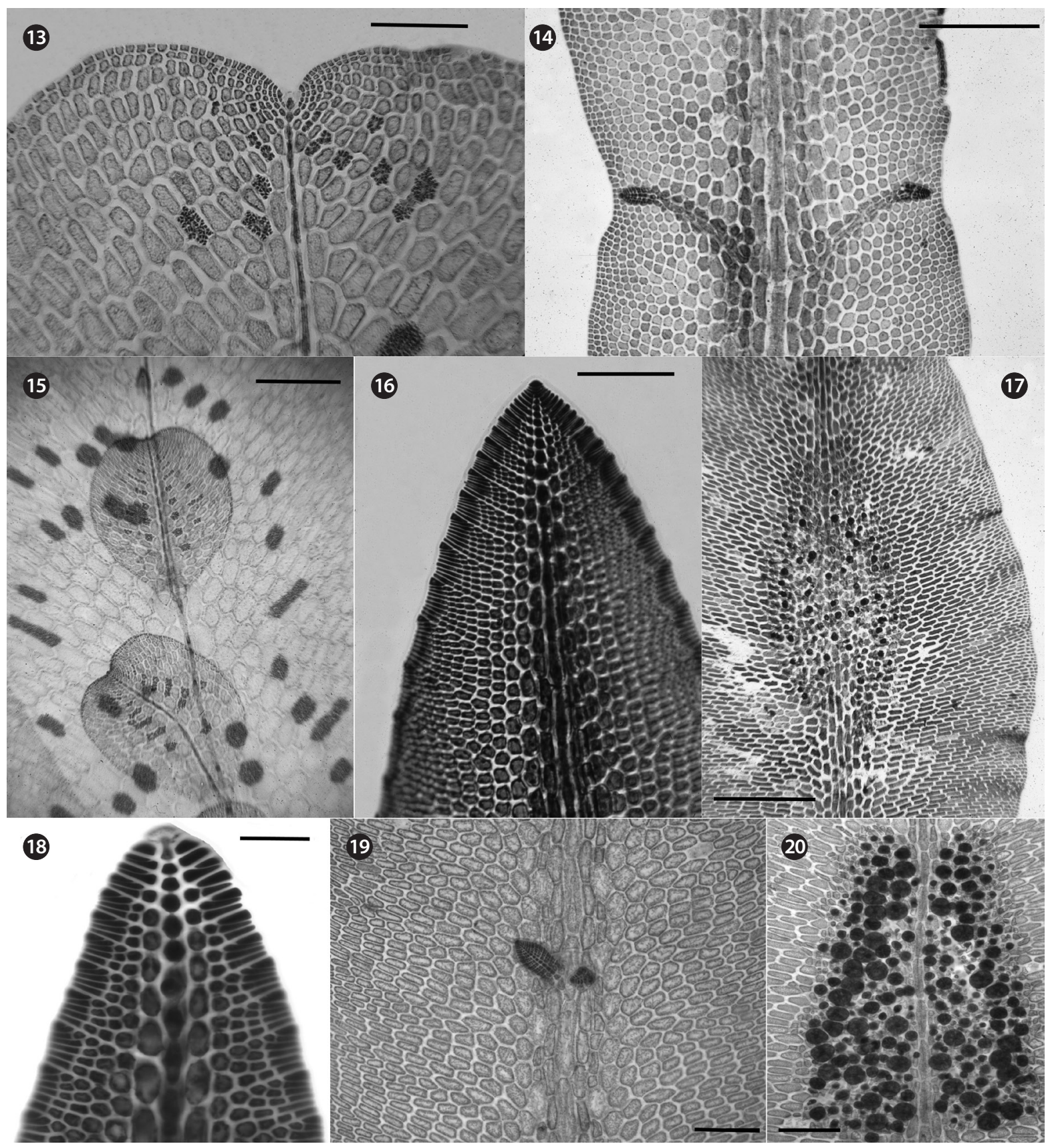

Figs 13-20. Figs 13 \& 15. Hypoglossum tenuifolium. [Puerto Rico, D. Ballantine 1518]. Fig. 13. Apex with Type-2 pattern. Fig. 15. Blade with scattered spermatangial sori. Figs 14, 16 \& 17. Hypoglossum anomalum. [Puerto Rico, D. Ballantine 1782]. Fig. 14. Pair of branch primordial emerging between midline and blade margin. Fig. 16. Apex with Type-1 pattern. Fig. 17. Blade with tetrasporangial sorus. Figs 18-20. Hypoglossum hypoglossoides. Fig. 18. Apex with Type-1 pattern. [North Carolina, USA, C. Schneider 862]. Figs 19 \& 20. [Bermuda, C. Schneider 0930-26]. Fig. 19. Branch arising from axial row. Fig. 20. Blade with tetrasporangial sorus. Scale bars represent: Figs $13,16 \& 18,40 \mu \mathrm{m}$; Figs 14 \& 15 , $100 \mu \mathrm{m}$; Fig. 17, $150 \mu \mathrm{m}$; Figs $19 \& 20,200 \mu \mathrm{m}$. 

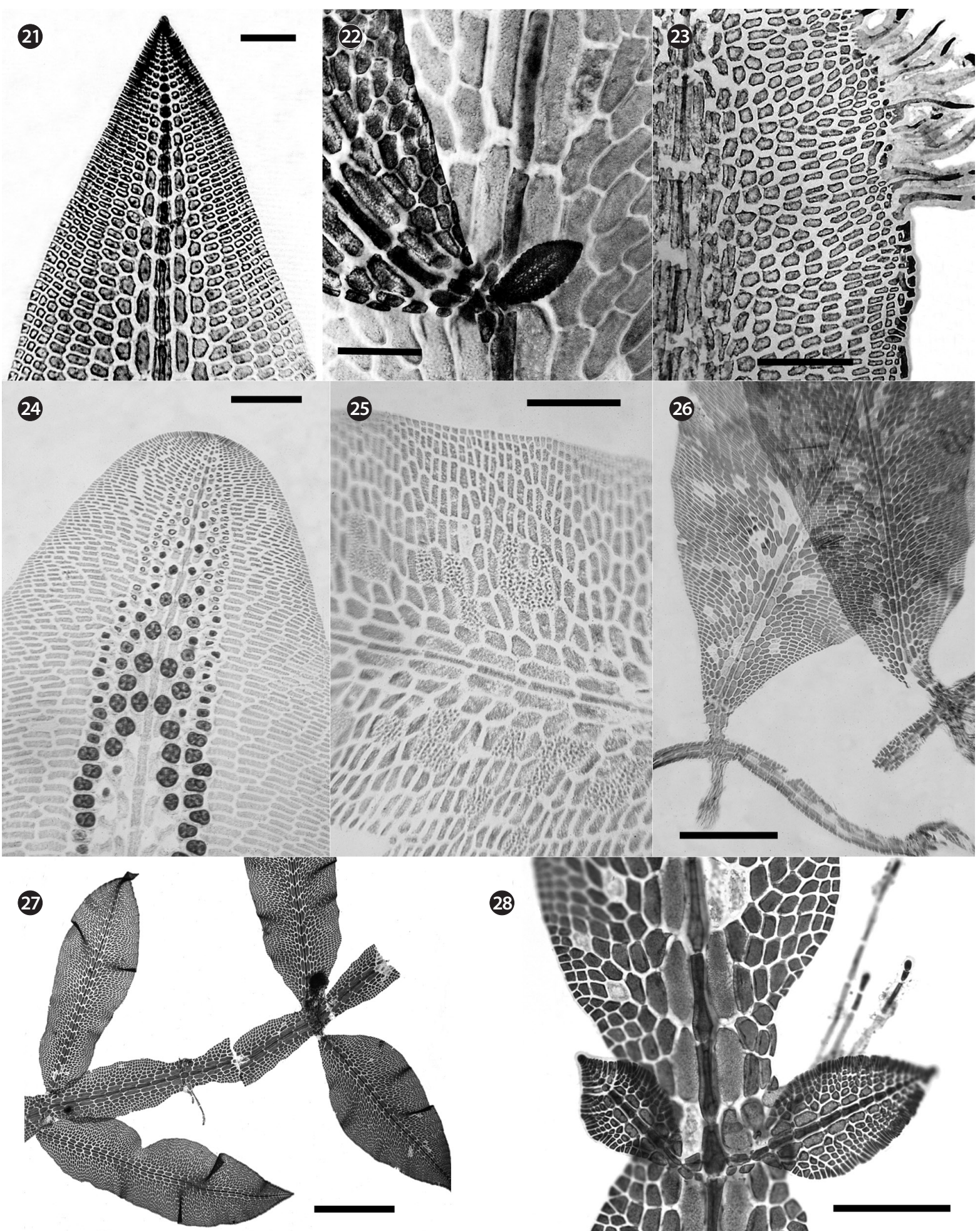

28

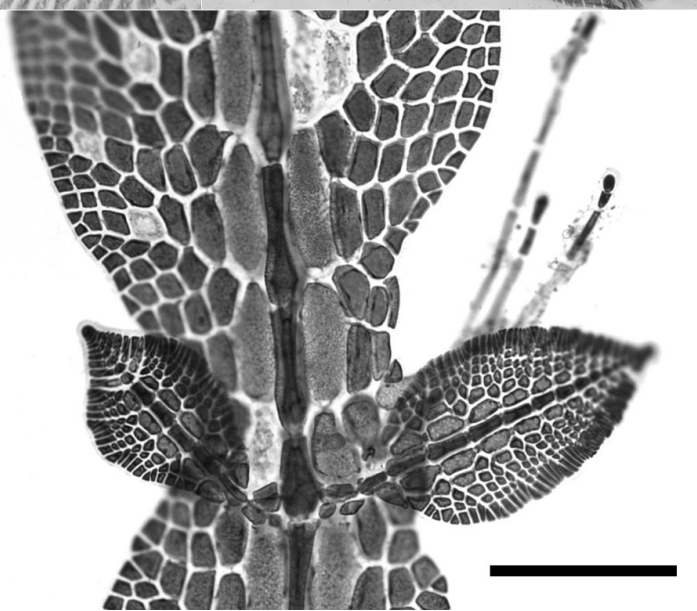

Figs 21-28. Figs 21 \& 22. Hypoglossum simulans. Fig. 21. Apex with Type-2 pattern. Fig. 22. Endogenous origin of branch from basal segment of parent blade. [Guadeloupe, D. Ballantine 2490] (after Wynne et al. 1989). Fig. 23. H. barbatum. Multicellular rhizoids produced from blade margin. [Bermuda, C. Schneider \& R. Searles 85-20-20] (after Schneider 2000). Figs 24 \& 25. H. subsimplex. Fig. 24. Blade with tetrasporangial sorus. Fig. 25. Blade with spermatangial sori. [Type collection, Florida, USA, M. Wynne 9959]. Fig. 26. H. rhizophorum. Habit. Isotype specimen [Puerto Rico, D. Ballantine 1750]. Figs 27 \& 28. H. caloglossoides. Fig. 27. Habit. Fig. 28. Constricted node with a pair of branches arising endogenously from central axial row. [Bermuda, C. Schneider \& C. Lane 01-22-14] (after Schneider 2004). Scale bars represent: Figs 21 \& 23-25, 50 $\mu \mathrm{m}$; Figs 22, 26 \& 28, $100 \mu \mathrm{m}$; Fig. 27, $0.5 \mathrm{~mm}$. 
scribed from deep water off North Carolina, USA (Schneider 1974). But Yoshida and Mikami (1991) later presented reasons to merge Searlesia within Polyneura while still recognizing P. subtropica (C. W. Schneid.) T. Yoshida et Mikami. Cyclospora, a name based on a type species from Florida and treated by Taylor (1960) as a genus of Delesseriaceae, was merged by Wynne (1985) into Carpoblepharis in the Ceramiaceae.

\section{Examples of new species based on western Atlantic types:}

Rhodophyta: Aglaothamnion flexibile (Aponte and Ballantine 1995), Antithamnionella bermudica (Schneider and Searles 1997), Antithamnionella schneideri (Athanasiadis 1996), Branchioglossum minutum (Schneider in Schneider and Searles 1975), B. prostratum (Schneider 1974), Calliblepharis occidentalis (Joly et al. 1965), Callithamniella silvae (Searles and Schneider 1989), Centroceras internitens (Gallagher and Humm 1983), Ceramium bisporum (Ballantine 1990), Ceramium fujianum (Barros-Barreto et al. 2006), Ceramium itonoi (Ardré 1987), Ceramium reptans (Cho and Fredericq 2006), Chamaebotrys prolifera (Ballantine et al. 2010), Champia feldmannii (Díaz-Piferrer 1977), Champia harveyana (Ballantine and Lozada-Troche 2008), Champia minuscula (Joly and Ugadim in Joly et al. 1966), Champia puertoricensis (Lozada-Troche and Ballantine 2010), Champia taironensis (Bula-Meyer 1997), Chondria platyramea (Joly and Ugadim in Joly et al. 1966), Chrysymenia littleriana and C. nodulosa (Norris and Ballantine 1995), Chylocladia schneideri (Ballantine 2004), Cirrulicarpus carolinensis (Hansen 1977), Corallina panizzoi (Schnetter and Richter 1979), Craspedocarpus humilis (Schneider 1988), Crouania elisiae (Schneider 2004), Crouania mayae (Mateo-Cid et al. 2002), Cryptonemia delicatula (Joly and Cordeiro in Joly et al. 1966), Cryptonemia flabellifolia (Pinheiro-Joventino and Oliveira 1977), Dasya abbottina (Ballantine and Aponte 2004) (Fig. 38), Dasya haitiana (Fredericq and Norris 1986), Dasya magnei (Ballantine 2000), Dasysiphonia concinna and D. doliformis (Schneider 1989), Diplothamnion jolyi (van den Hoek 1978), D. tetrastichum (Joly and Yamaguishi in Joly et al. 1966), Halymenia clathrata (Oliveira et al. 1976), Haralda tenuis (Oliveira 1969), Helminthocladia andersonii (Searles and Lewis 1983), Helminthora anomala (Vélez and Vega 2005) (Fig. 44), Herposiphonia xaymaca (Chapman 1963), Hypnea volubilis (Schneider and Searles 1976), Jania prolifera (Joly in Joly et al. 1966), Jania sanctae-marthae (Schnetter 1972), Kallymenia westii (Ganesan 1976) (Fig. 39), Lejolisea exposita (Searles and Schneider 1989), Ligora tsengii (Huisman and Wynne 1999) (Fig. 45), Lithophyllum depressum (Villas-Boas et al. 2009), Mazoyerella kraftii (Bucher and Norris 1995), Naccaria antillana (Taylor 1971), Nemalion cari-cariense (Schnetter 1972), Nitophyllum adhaerens (Wynne 1997), Perikladosporon abaxiale (Ballantine and Aponte 2005), Periphykon delesserioides (Joly et al. 1967), Petroglossum undulatum (Schneider and Searles 1976), Platysiphonia caribaea (Ballantine and Wynne 1985), Polysiphonia boldii (Wynne and Edwards 1970), P. plectocarpa (Schneider and Searles 1998), Porphyra acanthophora and P. spiralis (Oliveira and Coll 1975), Porphyra pujalsii and P. rizzinii (Coll and Oliveira 1976), Ramicrusta textilis (Pueschel and Saunders 2009), Schimmelmannia venezuelensis (Ballantine et al. 2003) (Fig. 40), Seirospora viridis (Aponte and Ballantine 1995), Stichothamnion antillarum (Vroman 1967), Titanophora submarina (Bucher and Norris 1992), Woelkerlingia sterreri (Schneider and Wynne 2009)

Heterokontophyta: Dictyopteris jolyana (Oliveira and Furtado 1978), Dictyota caribaea, D. guajirae and D. humifusa (Hörnig et al. 1992), Dictyota pulchella (Hörnig and Schnetter 1988), Laminaria abyssalis and L. brasiliensis (Joly and Oliveira 1967), Onslowia bahamensis (Henry 1987), Padina boergesenii (Allender and Kraft 1983) (Fig. 46), P. profunda (Earle 1969), Sargassum mathiesonii (Kilar 1992), Sargassum pusillum (Taylor 1975), Sargassum wolfii (Earle 1969), Stictyosiphon lutarius (Taylor 1974), Syringoderma floridana (Henry 1984)

Chlorophyta: Acetabularia myriospora (Joly et al. 1965), Avrainvillea cyathiformis (Ballantine and Aponte 2003), Boodleopsis vaucherioidea (Calderón-Sáenz and Schnetter 1989), Bryopsis halliae (Taylor 1962a) (Fig. 48), Caulerpa kempfii (Joly and Pereira 1975), Codium carolinianum (Searles 1972), Halimeda goreaui (Taylor 1962d) (Fig. 49), Halimeda pumila (Verbruggen et al. 2007b), Ostreobium constrictum (Lukas 1974), Pseudocodium floridanum (Dawes and Mathieson 1972), Rhipidosiphon floridensis (Littler and Littler 1990a), Trichosolen molassensis (Bucher and Norris in Bucher et al. 1990)

A number of genera have received monographic treatments, have otherwise relatively large levels of attention, or have had new species assigned. These genera are listed below with citations of their treatments:

Aglaothamnion and Callithamnion: Aponte and Ballantine (1990, 1995); Aponte et al. (1994, 1997); Brasileiro et al. (2009); Cordeiro-Marino (1978); Dixon and Price (1981); Guimarães (2006); L'Hardy-Halos and Rueness (1990); Maggs et al. (1991); Rueness and L'Hardy-Halos (1991); Rueness and Rueness (1980); Schneider (1980); Searles (1981); Wynne (2005) 

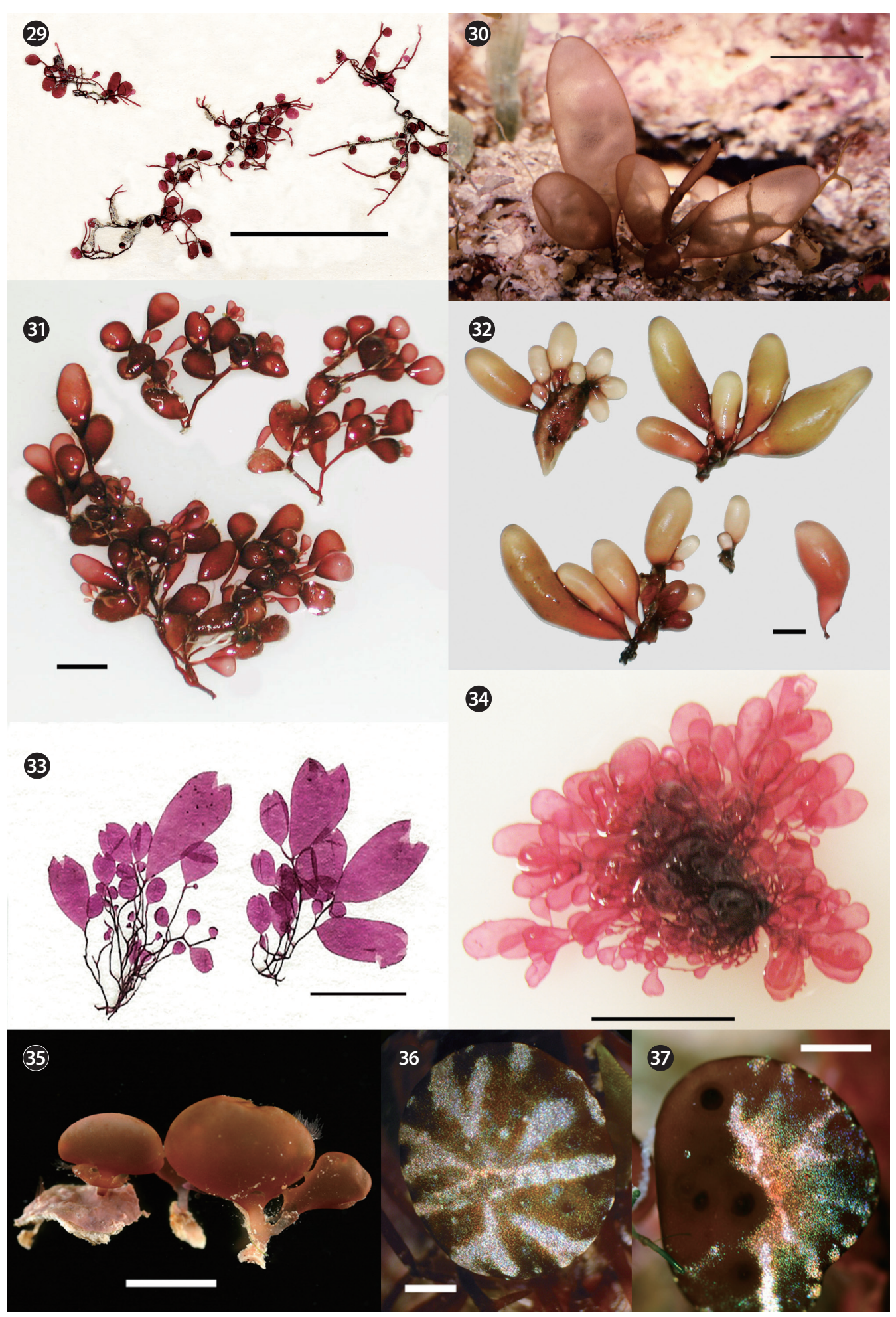

Figs 29-37. Fig. 29. Botryocladia spinulifera. [U.S. Virgin Is., N. Ogden N-490]. Habit, pressed specimen. Fig. 30. B. wynnei. [Puerto Rico, Ballantine]. In situ specimens. Fig. 31. B. bermudana. [Bermuda, C. Schneider \& C. Lane 02-11-1]. Aquarium specimens. Fig. 32. B. flookii. [Bermuda, C. Schneider \& C. Lane 03-16-9]. Habit of living specimens. Figs 33 \& 34. B. exquisita. [Bermuda, C. Schneider \& C. Lane 08-16-2]. Fig. 33. Habit of an isotype. Fig. 34. Habit of type collection. Figs 35-37. B. iridescens. Fig. 35. Wet habit of Holotype. [Puerto Rico, D. Ballantine 6342]. Fig. 36. Vesicle showing a stellate pattern of iridescence. [Puerto Rico, D. Ballantine 6307]. Fig. 37. Vesicle showing a spotted pattern of iridescence. [Puerto Rico, D. Ballantine 6376] (Figs 35-37 after Ballantine and Ruiz 2008). Scale bars represent: Fig. 29, 3 cm; Fig. 30, 4 mm; Figs 31-33, 1 cm; Fig. 34, 2 cm; Fig. 35, 5 mm; Fig. 36, 1 mm; Fig. 37, 2 mm. 

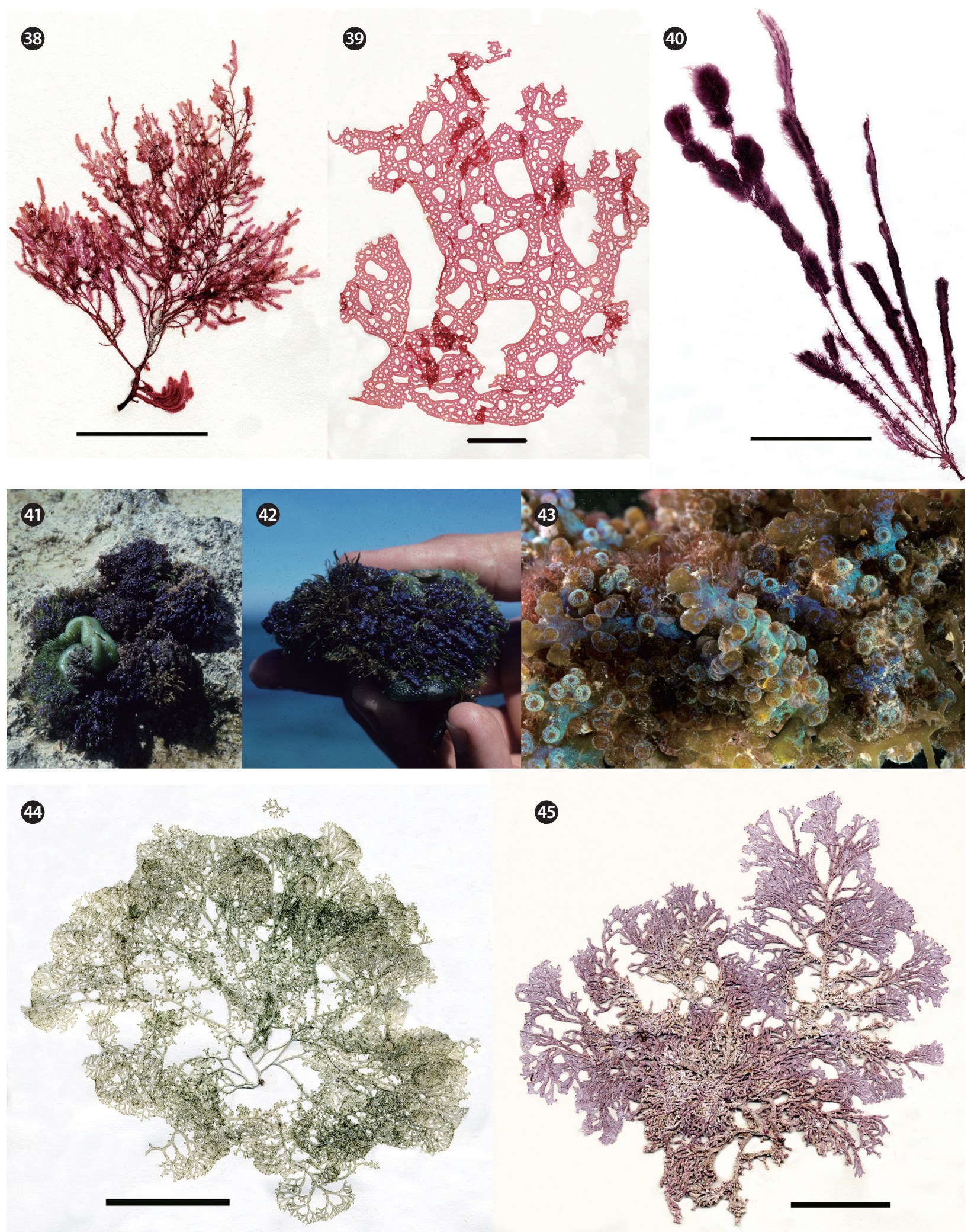

Figs 38-45. Fig. 38. Dasya abbottiana. Habit. [lsotype, Puerto Rico, H. Ruiz \& D. Ballantine 6100]. Fig. 39. Kallymenia westii. Habit. [Venezuela, Wynne 7862]. Fig. 40. Schimmelmannia venezuelana. Habit. [Holotype, Venezuela, M. García 48]. Figs 41-43. Palisada iridescens (M. J. Wynne \& D. L. Ballant.) K.W. Nam. Figs 41 \& 42. Type collection, Guadeloupe, Ballantine \& Wynne. Fig. 43. Puerto Rico, H. Rúiz \& D. Ballantine 8263. Fig. 44. Helminthora anomala. Habit. [Holotype, Puerto Rico, R. Vega \& C. García 4202]. Fig. 45. Liagora tsengii. Habit. [Holotype, St. Kitts, M. Edlund \& M. Wynne 10663]. Scale bars represent: Figs $38,44 \& 45,3 \mathrm{~cm}$; Figs $39 \& 40,6 \mathrm{~cm}$. 

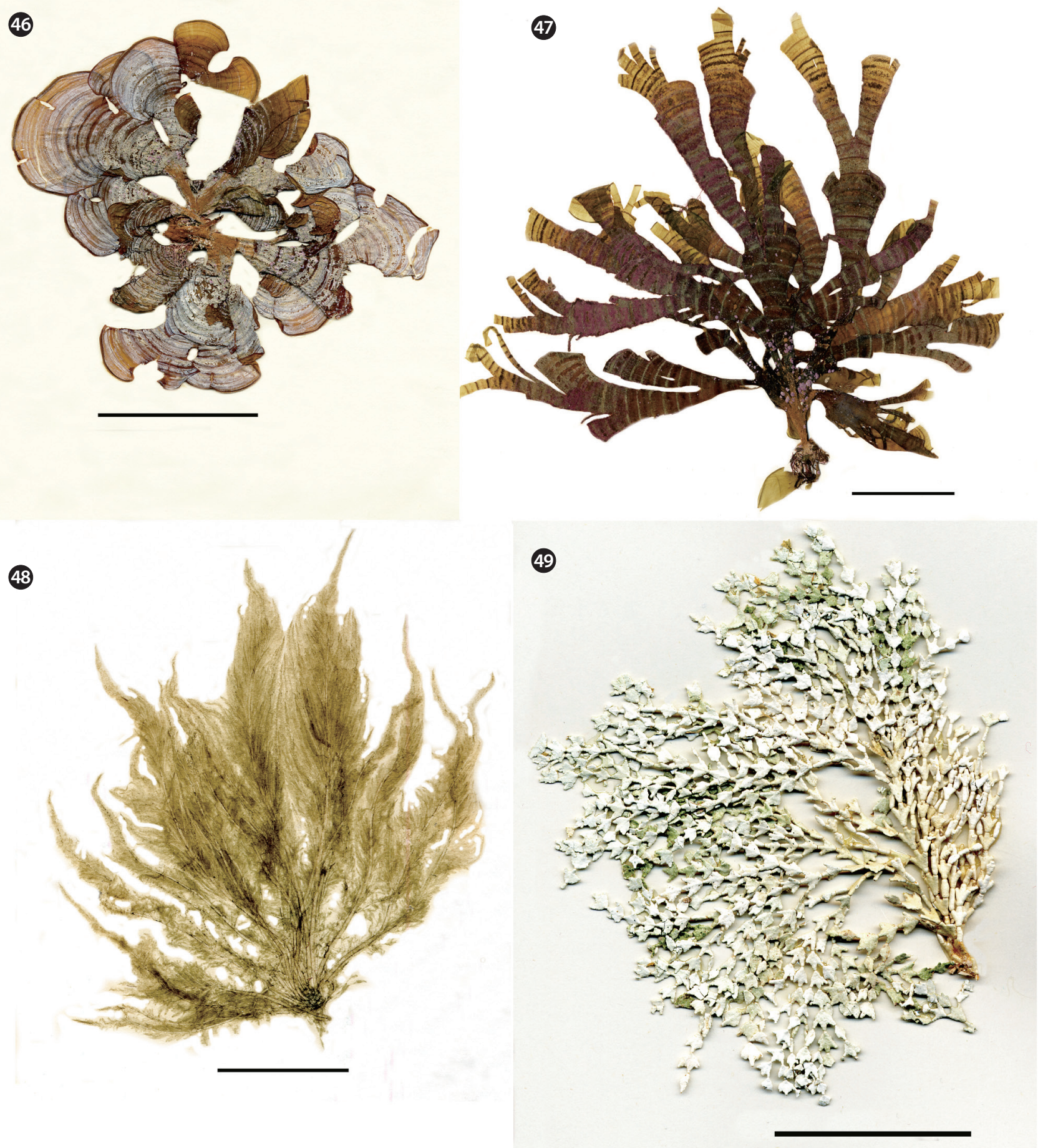

Figs 46-49. Fig. 46. Padina boergesenii. Habit. [Guadeloupe, M. Wynne 8320]. Fig. 47. Padina glabra. Habit. [Texas, USA, M. Wynne 2588]. Fig. 48. Bryopsis halliae. Habit. [Isotype, Florida, USA, Mrs. G. Hall]. Fig. 49. Halimeda goreaui. Habit. [Isotype, Jamaica, T. Goreau \& J. Lang]. Scale bars represent: $3 \mathrm{~cm}$. 
Dudresnaya: Eiseman and Norris (1981); Searles (1983); Searles and Ballantine (1986)

Gracilaria: Bodard (1965); Gurgel and Fredericq (2004); Gurgel et al. (2004a, 2004b, 2004c, 2008); Hommersand and

Freshwater (2009); McLachlan (1979); Pinheiro and Joly (1966); Plastino and Oliveira (1997, 2002)

Gracilariopsis: Bird and Oliveira (1986); Fredericq and Hommersand (1989); Gurgel et al. (2003a, 2003b)

Peyssonnelia: Ballantine and Aponte (2005); Ballantine and Ruíz (2005, 2006, 2007, 2010, 2011); Boudouresque and Deni-

zot (1975); Joly et al. (1968); Marcot-Coqueugniot (1988); Schneider and Reading (1987); Yoneshigue (1984)

Anadyomene: Joly and Pereira (1973); Joly and Oliveira (1968); Littler and Littler (1991)

Avrainvillea: Joly et al. (1966); Littler and Littler (1992)

Cladophora: Norris and Olsen (1991); van den Hoek (1969, 1982); van den Hoek and Searles (1988)

Halimeda: Ballantine (1982); Colinvaux and Graham (1964); Dawes (1980); Dawes and Humm (1969); Goreau and Graham (1967); Guimarais et al. (2009a, 2009b); Hillis (1959); Hillis-Colinvaux (1980); Taylor (1962d); Verbruggen et al. (2005); Verbruggen et al. (2007b)

Udotea: Littler and Littler (1990b)

Verdigellas: Ballantine and Aponte (1996); Ballantine and Norris (1994)

\section{Examples of new records for the western Atlantic:}

The red alga Reticulocaulis mucosissimus I. A. Abbott was described from 8-10 m depths off Hawaii by Abbott (1985), and so the discovery of its presence from Espírito Santo State, Brazil, by Guimarães and Amado-Filho (2009) is an interesting range extension. Earlier, it has been found to occur in Oman (Schils et al. 2003) and the Canary Islands (AfonsoCarrillo et al. 2006). A comparable case is the report by Ballantine et al. (2009) of Predaea laciniosa from Puerto Rico, representing the first record of this species from the Atlantic Ocean. This species was described by Kraft (1984) with a type locality of Heron Island, Great Barrier Reef, Australia.

Laurencia pygmaea Weber Bosse, a species with a type locality of Diego Garcia Atoll in the Indian Ocean (Weber van Bosse 1913) and previously unknown for the Atlantic Ocean, was reported from Brazil (Oliveira and Ugadim 1974) and Venezuela (Rodríguez de Rios and Lobo 1984). But several workers (Jaasund 1970, Furnari and Cormaci 1990, Wynne 1995) later treated it as conspecific with L. decumbens Kûtz., a species first described from New Caledonia (Kützing 1863).

The range of Padina glabra Gaillard, described from Dakar, Senegal, West Africa (Gaillard 1966), has been extended to the east coast of Florida (Wynne and De Clerck 1999) and to Texas (Wynne 2009a) (Fig. 47). It is a distinctive species because of the absence of hairs.

Van den Hoek and Rios (1972) reported the occurrence of Willeella ordinata Børgesen, a green algal species first described from Gujarat, India, to be present in Venezuela. Van den Hoek (1982) later reduced Willeella to the status of a section within Cladophora. Although some authors (e.g., Silva et al. 1996) continued to recognize Willeella as a genus, according to Wysor and Kooistra (2003) their separation as two discrete genera is not supported by molecular data.

Ballantine et al. (2009) reported the occurrence of Boergesenia forbesii (Harv.) Feldmann from Puerto Rico, representing the first record of this monotypic genus from the Atlantic. It is well known from various locations in the tropical IndoPacific, including Australia, southern Japan, China, Sri-Lanka, and the east coast of Africa.

Caulerpa ollivieri, a species that was described from the Mediterranean coast of France (Dostál 1929), was reported to occur in two deep-water sites in the Gulf of Mexico (Hine and Humm 1971). But more recently its invasive spread in the Bahamas has been reported by Lapointe et al. (2005), despite the fact that in its home range it has been listed as an endangered species by the Berne Convention (the European Centre for Nature Conservation).

Halimeda cuneata K. Hering in Krauss, a species with a type locality of Natal Bay, South Africa (Krauss 1846), was reported for the first time to occur in the Atlantic by its record from Brazil by Bandeira-Pedrosa et al. (2004). The authors expressed the opinion that earlier collections had likely been mistaken for H. discoidea or H. tuna or else had been called "Halimeda sp." Halimeda pygmaea, a species originally described from Astrolabe Reef, Fiji, South Pacific (Verbruggen et al. 2007b), was reported from Cuba by Guimarais et al. (2009b), representing its first record in the Atlantic.

Rhipilia tomentosa Kütz. was the only species in the genus included in Taylor's (1960) flora. Later, Joly and Sazima (1971) reported from Brazil R. orientalis A. Gepp et E. Gepp, described from the Malay Archipelago, Indonesia (Gepp and Gepp 1911) and R. diaphana W. R. Taylor, described from Bikini Atoll, Northern Marshall Islands (Taylor 1950). Rhipilia fungiformis was a newly described species from Itaparica Island, Bahía, Brazil by Joly and Ugadim (Joly et al. 1965). 
Oliveira (1977) pointed out that $R$. tenaculosa was described by Gepp and Gepp (1911) from deep water off Barra Grande, near Pernambuco, Brazil. But it was missed by Taylor (1960).

\section{Examples of clarifications of uncertain taxa:}

An ongoing task of workers in systematic phycology is the need to be aware of possible misunderstood taxa or of misinterpretations of the type specimens of taxa. One example is the work by Allender and Kraft (1983), who observed that the holotype of Padina gymnospora (Kütz.) Sond. [= Zonaria gymnospora Kütz.] was up to 8 or 9 cell layers in thickness and thus did not correspond to the contemporary idea of that species. They relegated $P$. vickersiae to the status as a taxonomic synonym of P. gymnospora and described the new species P. boergesenii (Fig. 46) to accommodate the Padina that had fit the wrong concept of $P$. gymnospora, a blade of 2-3 cell layers in thickness.

Similarly, De Clerck and Coppejans (1997) found the Holotype of Dictyota crispata J. V. Lamour. in the Lamouroux Herbarium in Caen, France, and recognized that concepts of that species and D. bartayresiana Kütz. had been confused by many workers. What Vickers (1908) and others had depicted as "Dictyota bartayresiana" agreed well with the type of D. crispata. This meant that D. neglecta Hörnig et Schnetter (Hörnig et al. 1992), which had been described to include the specimens of $D$. bartayresiana auct. non Vicker, becomes a superfluous name for $D$. bartayresiana.

An example of the consolidation of many (five) names into one recognized taxon is shown by Fiore's (1977) work, in which he used laboratory-based culturing studies to demonstrate that a heteromorphic life history was occurring in a brown alga occurring along the east coast of North America and the Gulf of Mexico. The larger sporophytic phase, a cylinder up to $12 \mathrm{~cm}$ tall and with parenchymatous construction, had gone under the name Stictyosiphon subsimplex Holden, and the smaller gametophytic phase, of 1-3 mm-tall tufts with sympodial growth, trichothallic hair formation, and lateral dimorphic plurilocular gametangia, had gone under the name Farlowiella onusta (Kütz.) Kornmann and several taxonomic synonyms. Fiore provided persuasive evidence that a single taxon was involved. Earlier, Fiore (1975) had proposed the new name Hummia to replace the illegitimate name Farlowiella Kornmann in Kuckuck (1956).

Bakothamnion was described by van den Hoek (1978), based on B. curassavicum Hoek from Curaçao, Netherland Antilles. But according to Young (1981), that species is conspecific with Balliella pseudocorticata (E. Y. Dawson) D. N. Young. The genus Balliella Itono et Tanaka (1973) was based on the type species B. crouanioides (Itono) Itono et T. Tanaka from Mage Island, southern Japan.

Dasya brasiliensis was described from Praia da Figueira, São Francisco, State of São Paulo, Brazil, by Oliveira and Braga (1971). But more recently Ritzmann et al. (2007) treated it as conspecific with the widely occurring D. rigidula (Kütz.) Ardiss.

An example of generic clarification was that on the Pseudobryopsis / Trichosolen complex by Henne and Schnetter (1999). Bryopsis duchassaingii J. Agardh was included by Tayor (1960), but later Taylor (1962a, 1962c) recognized that B. duchassaingii belongs to the genus Trichosolen (Montagne 1861). Taylor (1962c) treated Pseudobryopsis (Berthold in Oltmanns 1904) as congeneric with Trichosolen, both genera having specialized gametangia, a feature distinguishing them from Bryopsis. But Henne and Schnetter (1999) presented evidence for the generic distinction of Trichosolen and Pseudobryopsis on the basis of differences in the nature of the gametangia and the chloroplasts.

In the category of clarifications are those species that were long thought to be the same as familiar European species because of their remarkable superficial similarity. But modern tools of gene-sequencing have sometimes revealed instances of cryptic speciation, where the European-based types are genetically distinct from their western Atlantic counterpart. For example, De Clerck et al. (2005) have shown that Grateloupia filicina, despite its many reports from the western Atlantic and elsewhere, is limited to the Mediterranean basin. Some work will be required to determine if one or another of the names thought to be taxonomic synonyms might be available to serve for the western Atlantic material.

According to Stuercke and Freshwater (2008) the names Polysiphonia denudata (Dillwyn) Harv. and P. stricta (Dillwyn) Grev. [= P. urceolata (Dillwyn) Grev.] that have been applied to collections from the western Atlantic do not correspond to these European-based species on the basis of genes examined. In a later paper, Stuercke and Freshwater (2010) described two new species from the western Atantic. Polysiphonia schneideri, with a type locality of Wrightsville Beach, New Hanover County, North Carolina, USA, was used for material that had previously been mis-identified as P. denudata. They did not recognize P. denudata as present in the western Atlantic. The second new species, $P$. kapraunii, with a type locality of Masonboro Inlet, New Hanover County, North Carolina, USA, was used for some (but not all) material 
from the western Atlantic that had previously been been mis-identified as P. stricta (and its taxonomic synonym $P$. urceolata). They did recognize P. stricta as also present in the western Atlantic.

Several species of Gracilaria that were recognized as present in the western Atlantic by Taylor (1960) have subsequently been shown to have more restricted distributions. Plastino and Oliveira (1996) stated that G. verrucosa (Huds.) Papenf. does not occur in Brazil and probably not in the Caribbean. Later, Irvine and Steentoft (1995) presented arguments for the rejection of the basionym Fucus verrucosus Huds. Gracilariopsis longissima (S. G. Gmel.) M. Steentoft, L. M. Irvine et W. F. Farnham (1995) became the correct name for what had been called Gracilaria verrucosa in Europe, but other species of Gracilariopsis have been shown to be the correct names for related species in the western Atlantic, such as Gracilariopsis carolinensis (Gurgel et al. 2003b) as well as G. silvana, G. hommersandii, and G. cata-luziana (Gurgel et al. 2003a). Gracilaria tenuifrons, a species described from Algoas in northeastern Brazil by Bird and Oliveira (1986), was later transferred to Gracilariopsis by Fredericq and Hommersand (1989).

Some of Taylor's (1960) concept of "Gracilaria foliifera" was treated in part as G. intermedia by Gurgel et al. (2004b) and in part as the new species G. isabellana by Gurgel et al. (2004a). Wynne (2005) pointed out that the neglected but valid name G. patens P. Crouan et H. Crouan needs to be reinstated for Caribbean Gracilaria with thalli consisting of a spreading clump of mostly dichotomously branched, compressed axes and for which Taylor (1960) applied the incorrect name "G. foliifera." Taylor's (1960) "Gracilaria debilis," a species with a type locality of Al Mukha, Yemen, in the Red Sea, is thought not to be present in the western Atlantic (Bird et al. 1986) and is now known as Hydropuntia cornea (J. Agardh) M. J. Wynne (Wynne 1989). Another species that had been placed in Gracilaria by Taylor (1960), G. crassissima, is now assigned to Hydropuntia, and several other species have been either newly described or have been assigned to Hydropuntia (Rodríguez de Rios 1986, Wynne 1989, Gurgel and Fredericq 2004). Bird et al. (1986) offered reasons to dismiss the name G. wrightii (Turner) J. Agardh from the flora. Oliveira et al. (1983) presented evidence to merge Gracilaria ferox J. Agardh, a species that had been recognized by Taylor (1960), within G. cervicornis (Turner) J. Agardh.

Taylor (1960) recognized Halymenia floresii (Clemente) C. Agardh, the European-based generitype, as occurring in the western Atlantic. In additon, there was the morphologically similar H. pseudofloresii Collins et M. Howe, with Walsingham Pond, Bermuda, as type locality. Schneider et al. (2010) described the great morphological variability in specimens of $H$. pseudofloresii from Bermuda, and they also provided molecular evidence that $H$. pseudofloresii is sister to $H$. floresii. Using barcoding sequences, Schneider et al. (2010) demonstrated that the narrow to extremely broad specimens all represented a single taxon in the islands and removed $H$. floresii from the flora. Furthermore, they questioned all other records of $H$. floresii from the western Atlantic until they are positively compared with the European generitype.

According to Wang et al. (2005), molecular data do not support the monophyly of such putatively pantropical species as Dichotomaria marginata (J. Ellis et Sol.) Lam., D. obtusata (J. Ellis et Sol.) Lam., and Galaxaura rugosa (J. Ellis et Sol.) J.V. Lamour. Cryptic speciation may be present in those species.

Another example of cryptic species being recognized and separated is the work by Ballantine and Lozada-Troche (2008), who showed that Champia harveyana, their new species from Puerto Rico, can be distinguished from the similar C. salicornioides Harv. The two species are sister taxa in the same clade but differ on internal morphologies, different branching patterns, and also on sequence analyses of two genes. Similarly, Champia puertoricensis was recognized as a new species by Lozada-Troche and Ballantine (2010) from sympatrically occurring C. parvula (C. Agardh) Harv. on the basis of differences in branching pattern, origin of branches, monoecious or dioecious conditions, and gene sequences. Bula-Meyer (1997) was able to separate out Champia taironensis, a new species from the Caribbean coast of Colombia, from two other flattened species of the genus, C. compressa Harv. and C. vieillardii Kütz., by a suite of differences.

Dictyota dichotoma (Hudson) J. V. Lamour. had been long reported from the American Atlantic, but Schnetter et al. (1987) were able to demonstrate that the American plants were not interfertile with European plans, and they had different chromosome numbers. So the name D. menstrualis (Hoyt) Schnetter, Hörnig et Weber-Peukert was applied to the American counterpart.

Dictyota pfaffii was described from Punta Brava, Isla Grande, on the Caribbean coast of Colombia by Schnetter (1972). But De Clerck (2003) and Wysor and De Clerck (2003) have presented arguments to regard D. pfaffii as conspecific with D. friabilis Setch., a species described from Tahiti (Setchell 1926).

Some instances of invasive species have been reported. Gracilaria vermiculophylla (Ohmi) Papenf., with a type locality of Akkeshi Bay, Hokkaido, Japan, has earlier been reported from many sites on the coast of Atlantic Europe, where it is regarded as an invasive (Rueness 2005). It was first reported from the east coast of North America from Virginia (Thom- 
sen et al. 2006) and next from North Carolina (Freshwater et al. 2006). Porphyra yezoensis Ueda, a species being commercially cultivated in Japan and China (Tseng 1981), has been reported to have spread into the North Atlantic, including New England, USA (Neefus et al. 2008). Molecular evidence of its presence on the coast of Texas has also been reported (Wynne 2009b). There was a deliberate introduction of the carrageenophytes Eucheuma denticulatum (Burman) Collins et Herv. and Kappaphycus alvarezii (Doty) P. C. Silva into waters of Venezuela and Brazil for commercial utilization. The invasive potential of $K$. alvarezii in waters off the state of Rio de Janeiro was considered remote (Castelar et al. 2009).

All of these various circumstances of the past half century, including expanded exploration into previously uncharted areas and using SCUBA for collecting at greater depths, the increase in the number of phycologists in countries of the tropical and subtropical western Atlantic Ocean, and the use of new technologies of gene-sequencing combined with phylogenetic analyses, have resulted in significant changes in the number of taxa of benthic marine algae. This fact applies to all hierarchical ranks, from infraspecific taxa and species to orders and classes. Many examples can be cited of the recognition that the application of names of species based on European types for western Atlantic material has not been correct. Also, the utilization of molecular systematics has often led to the appreciation of cryptic speciation and that what had been regarded to be widely occurring species actually represent species complexes. It is anticipated that these trends will continue as will be expected the introduction of invasive species into this flora.

\section{ACKNOWLEDGEMENTS}

I am grateful to Dr. Craig W. Schneider of Trinity College, Hartford, CT, and Dr. David L. Ballantine of the University of Puerto Rico, Mayaguez, for allowing me to include some of their images in this article. I thank Ms. Daniela Starr of PC Helps Support, LLC, Philadelphia, for her remote assistance in preparing the plates.

\section{REFERENCES}

Abbott, I. A. 1970. Yamadaella, a new genus in the Nemaliales (Rhodophyta). Phycologia 9:115-123.

Abbott, I. A. 1984. Two new species of Liagora (Nemaliales, Rhodophyta) and notes on Liagora farinosa Lamouroux. Am. J. Bot. 71:1015-1022.

Abbott, I. A. 1985. Vegetative and reproductive morphology in Reticulocaulis gen. nov. and Naccaria hawaiiana sp. nov. (Rhodophyta, Naccariaceae). J. Phycol. 21:554-561.

Abbott, I. A. 1990. A taxonomic assessment of the species of Liagora (Nemaliales, Rhodophyta) recognized by J. Agardh, based upon studies of type specimens. Cryptogam. Bot. 1:308-322.

Abbott, I. A. \& Doty, M. S. 1960. Studies in the Helminthocladiaceae. II. Trichogloeopsis. Am. J. Bot. 47:632-640.

Abe, T., Kurihara, A., Kawaguchi, S., Terada, R. \& Masuda, M. 2006. Preliminary report on the molecular phylogeny of the Laurencia complex (Rhodomelaceae). Coast. Mar. Sci. 30:209-213.

Afonso-Carrillo, J., Sansón, M. \& Sangil, C. 2006. First report of Reticulocaulis mucosissimus (Naccariaceae, Rhodophyta) for the Atlantic Ocean. Cryptogam. Algol. 27:255-264.

Allender, B. M. \& Kraft, G. T. 1983. The marine algae of Lord Howe Island (New South Wales): the Dictyotales and
Cutleriales (Phaeophyta). Brunonia 6:73-130.

Aponte Díaz, M. 1988. Botryocladia ganesanii sp. nov. (Rhodophyta, Rhodymeniales) from the Caribbean coast of Venezuela. Cryptogam. Algol. 9:43-52.

Aponte, N. E. \& Ballantine, D. L. 1990. The life history in culture of Callithamnion boergesenii sp. nov. (Ceramiaceae, Rhodophyta) from the Caribbean. Phycologia 29:191-199.

Aponte, N. E. \& Ballantine, D. L. 1995. Aglaothamnion flexibile sp. nov. and Seirospora viridis sp. nov. (Ceramiaceae, Rhodophyta) from Puerto Rico. Phycologia 34:102-112.

Aponte, N. E., Ballantine, D. L. \& Norris, J. N. 1994. Culture studies on the morphology and life history of Aglaothamnion herveyi (Howe) comb. nov., with notes on $A$. felipponei (Howe) comb. nov. (Ceramiaceae, Rhodophyta). Phycologia 33:231-238.

Aponte, N. E., Ballantine, D. L. \& Norris, J. N. 1997. Aglaothamnion halliae comb. nov. and A. collinsii sp. nov. (Ceramiales, Rhodophyta): resolution of nomenclatural and taxonomic confusion. J. Phycol. 33:81-87.

Ardré, F. 1987. Observations sur quelques espèces du genre Centroceras (Ceramiaceae, Rhodophyta). Cryptogam. Algol. 8:281-300.

Areces, A. J., Sentíes, A. \& Zayas, C. R. 2003. Nuevas adiciones al género Laurencia (Ceramiales, Rhodophyta) para el archipiélago cubano. Ser. Oceanológica (1):104-107. 
Aregood, C. C. 1975. A study of the red alga, Calonitophyllum medium (Hoyt) comb. nov. (=Hymenena media (Hoyt) Taylor). Br. Phycol. J. 10:347-362.

Athanasiadis, A. 1996. Morphology and classification of the Ceramioideae (Rhodophyta) based on phylogenetic principles. Opera Bot. 128:1-216.

Athanasiadis, A. 1998. Crouanophycus Athanasiadis, nom. nov. (Crouaniella Athanasiadis 1996, nom. illeg.), a new genus of the Crouanieae (Ceramiales, Rhodophyta). Nova Hedwigia 67:517-518.

Bailey, G. P., Rezak, R. \& Cox, E. R. 1976. A revision of generic concepts of living members in the subfamily Acetabularieae (Dasycladaceae, Dasycladales) based on scanning electron microscopy. Phycologia 15:7-18.

Ballantine, D. L. 1982. Halimeda hummii sp. nov., Halimeda cryptica v. acerifolia var. nov. (Caulerpales, Chlorophyta), and additional records of Halimeda species from Puerto Rico. J. Phycol. 18:86-91.

Ballantine, D. L. 1985. Botryocladia wynnei sp. nov. and $B$. spinulifera (Rhodymeniales, Rhodophyta) Taylor \& Abbott from Puerto Rico. Phycologia 24:199-204.

Ballantine, D. L. 1990. Ceramium bisporum (Rhodophyta, Ceramiales), an unusual new species from deep-water habitats in the Caribbean. Phycologia 29:146-149.

Ballantine, D. L. 1996. New records of benthic marine algae from Florida. Gulf Mex. Sci. 1:11-15.

Ballantine, D. L. 2000. Dasya magnei sp. nov. (Dasyaceae, Rhodophyta) from the Caribbean Sea. Cryptogam. Algol. 21:149-155.

Ballantine, D. L. 2004. Chylocladia schneideri sp. nov. (Champiaceae, Rhodophyta) from Puerto Rico, Caribbean Sea. Cyptogam. Algol. 25:125-132.

Ballantine, D. L. \& Abbott, I. A. 2006. Ganonema vermiculare sp. nov. (Liagoraceae, Rhodophyta), a new species from Puerto Rico, Caribbean Sea. Bot. Mar. 49:122-128.

Ballantine, D. L. \& Aponte, N. E. 1995. Laurencia coelenterata (Rhodomelaceae, Rhodophyta), a new diminutive species from the Dry Tortugas, Florida. Bot. Mar. 38:417421.

Ballantine, D. L. \& Aponte, N. E. 1996. Verdigellas nektongammea (Tetrasporales, Chlorophyta), a new deep-water species from the Bahamas. Nova Hedwigia 62:425-429.

Ballantine, D. L. \& Aponte, N. E. 2002a. Botryocladia bahamense sp. nov. (Rhodymeniaceae, Rhodophyta) from the Bahamas, western Atlantic. Cryptogam. Algol. 23:123-130.

Ballantine, D. L. \& Aponte, N. E. 2002b. Ganonema farinosum and Ganonema dendroideum comb. nov. (Liagoraceae, Rhodophyta) from Puerto Rico, Caribbean Sea. Cryptogam. Algol. 23:211-222.
Ballantine, D. L. \& Aponte, N. E. 2003. An annotated checklist of deep-reef benthic marine algae from Lee Stocking Island, Bahamas (western Atlantic), I. Chlorophyta and Heterokontophyta. Nova Hedwigia 76:113-127.

Ballantine, D. L. \& Aponte, N. E. 2004. Daysa abbottiana sp. nov. (Dasyaceae, Rhodophyta) from Puerto Rico, Caribbean Sea. Cryptogam. Algol. 25:409-417.

Ballantine, D. L. \& Aponte, N. E. 2005. An annotated checklist of deep-reef benthic marine algae from Lee Stocking Island, Bahamas (western Atlantic). II. Rhodophyta. Nova Hedwigia 80:147-171.

Ballantine, D. L., García, M., Gomez, S. \& Wynne, M. J. 2003. Schimmelmannia venezuelensis sp. nov. (Gloiosiphoniaceae, Rhodophyta) from Venezuela. Bot. Mar. 46:450455.

Ballantine, D. L. \& Lozada-Troche, C. 2008. Champia harveyana sp. nov. (Champiaceae, Rhodophyta) from Puerto Rico, Caribbean Sea. Bot. Mar. 51:388-398.

Ballantine, D. L. \& Norris, J. N. 1994. Verdigellas, a new deepwater genus (Tetrasporales, Chlorophyta) from the tropical Western Atlantic. Cryptogam. Bot. 4:368-372.

Ballantine, D. L. \& Ruíz, H. 2005. Two Peyssonnelia species (Peyssonneliaceae, Rhodophyta) from Puerto Rico, including Peyssonnelia flavescens sp. nov. Phycologia 44:328-334.

Ballantine, D. L. \& Ruíz, H. 2006. Peyssonnelia imbricata sp. nov. (Peyssonneliaceae, Rhodophyta) from Puerto Rico, Caribbean Sea. Bot. Mar. 49:431-437.

Ballantine, D. L. \& Ruíz, H. 2007. Erratum: Peyssonnelia imbricata sp. nov. (Peyssonneliaceae, Rhodophyta) from Puerto Rico, Caribbean Sea. Bot. Mar. 49 (2006):431-437. Bot. Mar. 50:72.

Ballantine, D. L. \& Ruiz, H. 2008. Botryocladia iridescens sp. nov. (Rhodymeniaceae, Rhodophyta) from Puerto Rico, Caribbean Sea. Cryptogam. Algol. 29:293-302.

Ballantine, D. L. \& Ruíz, H. 2010. Two new deepwater Peyssonnelia species, Peyssonnelia iridescens and Peyssonnelia gigaspora (Peyssonneliaceae, Rhodophyta) from Puerto Rico, Caribbean Sea. Phycologia 49:537-544.

Ballantine, D. L. \& Ruiz, H. 2011. A new encrusting deep-water coral reef alga, Peyssonnelia incomposita (Peyssonneliaceae, Rhodophyta), from Puerto Rico, Caribbean Sea. Cryptogam. Algol. 32:19-26.

Ballantine, D. L., Ruiz, H. \& Aponte, N. E. 2009. Notes on the benthic marine algae of Puerto Rico. IX. Additions to the flora including reports of three species for the first time in the Atlantic Ocean. Bot. Mar. 52:229-235.

Ballantine, D. L., Ruiz, H. \& Lozada-Troche, C. 2010. Chamaebotrys prolifera sp. nov. (Rhodymeniaceae, Rhodophyta) from Puerto Rico, Caribbean Sea, based on morphology 
and small subunit rDNA sequences. Phycol. Res. 58:69-77.

Ballantine, D. L., Ruiz, H. \& Wynne, M. J. 2002. Notes on the marine algae of Puerto Rico VII. Seven new records of benthic Rhodophyta. Caribb. J. Sci. 38:252-256.

Ballantine, D. L. \&Wynne, M. J. 1985. Platysiphonia and Apoglossum (Delesseriaceae, Rhodophyta) in the tropical western Atlantic. Phycologia 24:459-465.

Ballantine, D. L. \&Wynne, M. J. 1988. The life history and development of Hypoglossum rhizophorum (Delesseriaceae, Rhodophyta) in culture, a new deep-water species from the Caribbean. J. Phycol. 24:8-12.

Bandeira-Pedrosa, M. E., Barreto Pereira, S. M., Bouzon, Z. L. \& Oliveira, E. C. 2004. Halimeda cuneata (Bryopsidales, Chlorophyta), a new record for the Atlantic Ocean. Phycologia 43:50-57.

Barros-Barreto, M. B. de, McIvor, L., Maggs, C. A. \& Ferreira, P. C. G. 2006. Molecular systematics of Ceramium and Centroceras (Ceramiaceae, Rhodophta) from Brazil. J. Phycol. 42:905-921.

Berger, S., Fettweiss, U., Gleissberg, S., Liddle, L. B., Richter, U., Sawitzky, H. \& Zuccarello, G. C. 2003. 18S rDNA phylogeny as evolution of cap development in Polyphysaceae (formerly Acetabulariaceae: Dasycladales, Chlorophyta). Phycologia 42:506-561.

Bird, C. J. \& Oliveira, F. E. C. de. 1986. Gracilaria tenuifrons sp. nov. (Gigartinales, Rhodophyta), a species from the tropical western Atlantic with superficial spermatangia. Phycologia 25:313-320.

Bird, C. J., Oliveira, E. C. de \& McLachlan, J. 1986. Gracilaria cornea, the correct name for the western Atlantic alga hitherto known as G. debilis (Rhodophyta, Gigartinales). Can. J. Bot. 64:2045-2051.

Bodard, M. 1965. Le Gracilaria occidentalis (Borg.): une espèce de Rhodophycée pantropicale Atlantique. Bull. Mus. Natl. Hist. Natl. Paris Sér. 2 36:874-878.

Børgesen, F. 1917. The marine algae of the Danish West Indies. Part III. Rhodophyceae 3. Dansk Bot. Arkiv 3(1c):145-240.

Boudouresque, C. -F. \& Denizot, M. 1975. Révision du genre Peyssonnelia (Rhodophyta) en Méditerranée. Bull. Mus. Hist. Nat. Marseille 35:7-92.

Brasileiro, P. S., Yoneshigue-Valentin, Y., Bahía, R. da G., Reis, R. P. \& Amado Filho, G. M. 2009. Algas marinhas bentônicas de região de Cabo Frio arredores: sintese do conhecimento. Rodriguésia 60:39-66.

Bucher, K. E. \& Norris, J. N. 1992. A new deep-water red alga, Titanophora submarina sp. nov. (Gymnophloeaceae, Gigartinales), from the Caribbean Sea. Phycologia 31:180191.

Bucher, K. E. \& Norris, J. N. 1995. Marine algae new to the
Lesser Antilles, including Mazoyerella kraftii sp. nov. (Ceramiales, Rhodophyta). Caribb. J. Sci. 31:1-24.

Bucher, K. E., Norris, J. N., Littler, M. M. \& Littler, D. S. 1990. Marine algae new to Florida, including Trichosolen molassensis sp. nov. (Chlorophyta) and Diplothamnion jolyi var. ecellulare var. nov. (Rhodophyta). Cryptogam. Bot. 1:295-307.

Bula-Meyer, G. 1980. Cladophyllum schnetteri, a new genus and species of Sargassaceae (Fucales Phaeophyta) from the Caribbean coast of Colombia. Bot. Mar. 23:555-562.

Bula-Meyer, G. 1985. Champiocolax sarae gen. et sp. nov., an adelphohemiparasite of the Champiaceae (Rhodymeniales, Rhodophyta). Phycologia 24:429-435.

Bula-Meyer, G. 1997. Las especies de Champia (Rhodophyta: Champiaceae) de talo aplanado y una nueva del Caribe Colombiano. Caldasia 19:83-90.

Calderón, E. \& Schnetter, R. 1991. Pseudoderbesia, nuevo género de algas marinas (Bryopsidaceae, Chlorophyta). Caldasia 16:285-294.

Calderón-Sáenz, E. \& Schnetter, R. 1989. The life histories of Boodleopsis vaucherioidea sp. nov. and B. pusilla (Caulerpales) and their phylogenetic implications. Phycologia 28:476-490.

Carvalho, L. R. de, Fujii, M. T., Roque, N. F., Kato, M. J. \& Lago, J. H. G. 2003. Aldingin A, new brominated sesquiterpene from red algae Laurencia aldingensis. Tetrahedron Lett. 44:2637-2640.

Cassano, V. 2009. Taxonomia e filogenia do complexo Laurencia (Ceramiales, Rhodophyta), com ênfase no estado do Rio de Janeiro, Brasil. Tese apresentada ao Instituto de Botânica da Secretaria do Meio Ambiente, como parte dos requisitos exigidos para a obtenção do titulo de Doutour em Biodiversidade Vegetale e Meio Ambiente, São Paulo, 328 pp.

Cassano, V., Díaz-Larrea, J., Sentíes, A., Oliveira, M. C., GilRodríguez, M. C. \& Fujii, M. T. 2009. Evidence for the conspecificity of Palisada papillosa with $P$. perforata (Ceramiales, Rhodophyta) from the western and eastern Atlantic Ocean on the basis of morphological and molecular analyses. Phycologia 48:86-100.

Cassano, V., Széchy, M. T. M. de \& Fujii, M. T. 2006. Laurencia caduciramulosa (Ceramiales, Rhodophyta) from Ilha Grande Bay, Rio de Janeiro, Brazil: a recent introduction into the Atlantic Ocean? Cryptogam. Algol. 27:265-277.

Cassano, V., Yoneshigue-Valentin, Y. \&Wynne, M. J. 2004. Elachistiella leptonematoides gen. et sp. nov. (Elachistaceae, Phaeophyceae) from Brazil. Phycologia 43:329-340.

Castelar, B., Reis, R. P., Moura, A. L. \& Kirk, R. 2009. Invasive potential of Kappaphycus alvarezii off the south coast of Rio de Janeiro state, Brazil: a contribution to envi- 
ronmentally secure cultivation in the tropics. Bot. Mar. 52:283-289.

Chapman, V. J. 1963. The marine algae of Jamaica. Part 2. Phaeophyceae and Rhodophyceae. Bull. Inst. Jam. Sci. Ser. 12:1-201.

Cho, G. Y., Lee, S. H. \& Boo, S. M. 2004. A new brown algal order, Ishigeales (Phaeophyceae), established on the basis of plastid protein-coding $r b c \mathrm{~L}$, $p s a \mathrm{~A}$, and $p s b \mathrm{~A}$ region comparisons. J. Phycol. 40:921-936.

Cho, T. O., Boo, S. M., Hommersand, M. H., Maggs, C. A., McIvor, L. \& Fredericq, S. 2008. Gayliella gen. nov. in the tribe Ceramieae (Ceramiaceae, Rhodophyta) based on molecular and morphological evidence. J. Phycol. 44:721-738.

Cho, T. O. \& Fredericq, S. 2006. Two creeping Ceramium species (Ceramiaceae, Rhodophyta) from the Florida Keys: C. reptans sp. nov. and recircumscription of $C$. codii (Richards) Mazoyer. Phycologia 45:495-504.

Choi, H. -G., Kraft, G. T., Kim, H. -S., Guiry, M. D. \& Saunders, G. W. 2008. Phylogenetic relationships among lineages of the Ceramiaceae (Ceramiales, Rhodophyta) based on nuclear small subunit rDNA sequence data. J. Phycol. 44:1033-1048.

Colinvaux, L. H. \& Graham, E. A. 1964. A new species of Halimeda. Nova Hedwigia 7:5-10.

Coll, J. \& Oliveira Filho, E. C. de 1976. The genus Porphyra C. Ag. (Rhodophyta-Bangiales) in the American South Atlantic. II. Uruguayan species. Bot. Mar. 19:191-196.

Cordeiro-Marino, M. 1978. Rodofíceas bentônicas marinhas do estado de Santa Catarina. Rickia 7:1-243.

Cordeiro-Marino, M. \& Fujii, M. T. 1985. Laurencia catarinensis (Rhodomelaceae, Rhodophyta), a new species from the Ilha de Santa Catarina, Brazil. Rev. Bras. Bot. 8:47-53.

Curtis, N. E., Dawes, C. J. \& Pierce, S. K. 2008. Phylogenetic analysis of the large subunit rubisco gene supports the exclusion of Avrainvillea and Cladocephalus from the Udoteaceae (Bryopsidales, Chlorophyta). J. Phycol. 44:761-767.

Dawes, C. J. 1980. A new variety of the calcareous coenocyte, Halimeda lacrimosa Howe (Chlorophyta, Siphonales). Bull. Mar. Sci. 30:142.

Dawes, C. J. \& Humm, H. J. 1969. A new variety of Halimeda lacrimosa Howe. Bull. Mar. Sci. 19:428-431.

Dawes, C. J. \& Mathieson, A. C. 1972. A new species of Pseudocodium (Chlorophyta Siphonales) from the west coast of Florida. Phycologia 11:273-277.

Dawes, C. J. \& Mathieson, A. C. 2008. The seaweeds of Florida. University of Florida Press, Gainesville, FL, $591 \mathrm{pp}$.

Dawson, E. Y. 1962. Additions to the marine flora of Costa
Rica and Nicaragua. Pac. Nat. 3:375-395.

De Clerck, O. 2003. The genus Dictyota in the Indian Ocean. Opera Bot. Belg. 13:1-205.

De Clerck, O. \& Coppejans, E. 1997. The genus Dictyota (Dictyotaceae, Phaeophyta) from Indonesia in the Herbarium Weber-van Bosse, including the description of Dictyota canaliculata spec. nov. Blumea 42:407-420.

De Clerck, O., Gavio, B., Fredericq, S., Bárbara, I. \& Coppejans, E. 2005. Systematics of Grateloupia filicina (Halymeniaceae, Rhodophyta), based on $r b c \mathrm{~L}$ sequence analyses and morphological evidence, including the reinstatement of G. minima and the description of G. capensis sp. nov. J. Phycol. 41:391-410.

De Clerck, O., Leliaert, F., Verbruggen, H., Lane, C. E., De Paula, J. C., Payo, D. A. \& Coppejans, E. 2006. A revised classification of the Dictyoteae (Dictyotales, Phaeophyceae) based on $r b c \mathrm{~L}$ and 26S ribosomal DNA sequence analyses. J. Phycol. 42:1271-1288.

Delépine, R. \& Asensi, A. 1975. Asteronema nov. gen. nouveau genre de Phéophycée australe. Bull. Soc. Bot. Fr. 122:295-304.

Díaz-Larrea, J., Sentíes, A., Fujii, M. T., Pedroche, F. F. \& Oliveira, M. C. 2007. Molecular evidence for Chondrophycus poiteaui var. gemmiferus comb. et stat. nov. (Ceramiales, Rhodophyta) from the Mexican Caribbean Sea: implications for the taxonomy of the Laurencia complex. Bot. Mar. 50:250-256.

Díaz-Piferrer, M. 1977. Champia feldmannii, a new species of Rhodophyta from Venezuela. Bull. Soc. Phycol. Fr. 22:40-46.

Díaz-Pulido, G. \& Bula-Meyer, G. 1997. Marine algae from oceanic atolls in the southwestern Caribbean (Albuquerque Cays, Courtown Cays, Serrana Bank, and Roncador Bank). Atoll Res. Bull. 448:1-18.

Diaz-Pulido, G. \& Díaz-Ruíz, M. 2003. Diversity of benthic marine algae of the Colombian Atlantic. Biota Colombiana 4:203-246.

Dixon, P. S. \& Price, J. H. 1981.The genus Callithamnion (Rhodophyta: Ceramiaceae) in the British Isles. Bull. Br. Mus. (Nat. Hist.) Bot. 9:99-141.

Dostál, R. 1929. Caulerpa ollivieri n. sp. la seconde espèce européene des Caulerpacées. Bull. Inst. Océanogr. Monaco 531:1-12.

Doty, M. S. 1978. Izziella abbottae, a new genus and species among the gelatinous Rhodophyta. Phycologia 17:3339 .

Doty, M. S. \& Meñez, E. G. 1960. Tiffaniella, a new genus in the Ceramiales. Trans. Am. Microsc. Soc. 79:135-144.

Draisma, S. G. A., Peters, A. F. \& Fletcher, R. L. 2003. Evolution and taxonomy in the Phaeophyceae: effects of the 
molecular age on brown algal systematics. In Norton, T. A. (Ed.) Out of the Past. Collected Reviews to Celebrate the Jubilee of the British Phycological Society. The British Phycological Society, Belfast, pp. 87-102.

Draisma, S. G. A., Prud'homme van Reine, W. F., Stam, W. T. \& Olsen, J. L. 2001. A reassessment of phylogenetic relationships within the Phaeophyceae based on RUBISCO large subunit and ribosomal DNA sequences. J. Phycol. 37:586-603.

Earle, S. A. 1969. Phaeophyta of the eastern Gulf of Mexico. Phycologia 7:71-254.

Earle, S. A. \&Young, J. R. 1972. Siphonoclathrus, a new genus of Chlorophyta (Siphonales: Codiaceae) from Panama. Occas. Pap. Farlow Herb. Harvard Univ. 3:1-4.

Eiseman, N. J. \& Earle, S. A. 1983. Johnson-sea-linkia profun$d a$, a new genus and species of deep-water Chlorophyta from the Bahama Islands. Phycologia 22:1-6.

Eiseman, N. J. \& Norris, J. N. 1981. Dudresnaya patula sp. nov., an unusual deep-water red alga from Florida. J. Phycol. 17:186-191.

Famà, P., Wysor, B., Kooistra, W. H. C. F. \& Zuccarello, G. C. 2002. Molecular phylogeny of the genus Caulerpa (Caulerpales, Chlorophyta) inferred from the chloroplast tufA gene. J. Phycol. 38:1040-1050.

Fan, K. -C. \&Wang, Y. -C. 1974. Studies on the marine algae of Hsisha Islands, China. I. Ganonema gen. nov. Acta Phytotaxon. Sin. 12:489-493.

Farghaly, M. S. \& Denizot, M. 1979. Le genre Rhipiliopsis. Définition et place dans les Caulerpales (Chlorophycées). Rev. Algol. Nouv. Ser. 14:169-184.

Faye, E. J., Shimada, S., Kogame, K. \& Masuda, M. 2004. A new red algal species Meristotheca dakarensis (Solieriaceae, Gigartinales) from Senegal, western Africa, with comments on the relegation of Meristiella Cheney to synonymy with Meristotheca J. Agardh. Cryptogam. Algol. 25:241-259.

Fiore, J. 1975. A new generic name for Farlowiella onusta (Phaeophyta). Taxon 24:497-498.

Fiore, J. 1977. Life history and taxonomy of Stictyosiphon subsimplex Holden (Phaeophyta, Dictyosiphonales) and Farlowiella onusta (Kützing) Kornmann in Kuckuck (Phaeophyta, Ectocarpales). Phycologia 16:301-311.

Fredericq, S. \& Hommersand, M. H. 1989. Comparative morphology and taxonomic status of Gracilariopsis (Gracilariales, Rhodophyta). J. Phycol. 25:228-241.

Fredericq, S. \& Norris, J. N. 1986. The structure and reproduction of Dasya haitiana sp. nov. (Dasyaceae, Rhodophyta) from the Caribbean Sea. Phycologia 25:185-196.

Fredericq, S. \& Norris, J. N. 1995. A new order (Rhodogorgonales) and family (Rhodogorgonaceae) of red algae composed of two tropical calciferous genera, Renouxia gen. nov. and Rhodogorgon. Cryptogam. Bot. 5:316-331.

Freshwater, D. W., Greene, J. K., Hamner, R. M. \& Montgomery, F. 2006. Seasonality of the invasive seaweed Gracilaria vermiculophylla along the southeastern coast of North Carolina. J. N. C. Acad. Sci. 122:49-55.

Fujii, M. T. \& Cordeiro-Marino, M. 1996. Laurencia translucida sp. nov. (Ceramiales, Rhodophyta) from Brazil. Phycologia 35:542-549.

Fujii, M. T., Guimarães, S. P. B. \& Alves, J. P. 2005. Ocorrência de Laurencia venusta (Ceramiales, Rhodophyta) no Espírito Santo, Brasil: distribuição biogeográfica disjunta ou introdução recente? In Org. Sociedade Brasileira de Ficologia (Ed.) Reunião Brasileira de Ficologia, Memórias do Museu Nacional, Série Livros 10, Rio de Janeiro, pp. 527-536.

Fujii, M. T., Guimarães, S. M. P. B., Gurgel, C. F. D. \& Fredericq, S. 2006. Characterization and phylogenetic affiities of the red alga Chondrophycus flagelliferus (Rhodomelaceae, Ceramiales) from Brazil on the basis of morphological and molecular evidence. Phycologia 45:432-441.

Fujii, M. T. \& Sentíes, A. 2005. Taxonomia do complexo Laurencia (Rhodomelaceae, Rhodophyta) do Brasil, com énfase nas especies des estados de São Paulo e do Espíritu Santo. In Sentíes, A. \& Dreckmann, K. M. (Eds.) Monografías Ficológicas Vol. 2. Universidad Autónoma de Metropolitana de Iztapalapa, Iztapalapa; Instituto de Botánica, São Paulo, pp. 69-135.

Furnari, G. \& Cormaci, M. 1990. A sister taxon of Laurencia minuta in the Mediterranean: L. minuta ssp. scammaccae ssp. nov. (Rhodophyta). Phycologia 29:532-536.

Gabrielson, P. W. \& Cheney, D. P. 1987. Morphology and taxonomy of Meristiella gen. nov. (Solieriaceae, Rhodophyta). J. Phycol. 23:481-493.

Gaillard, J. 1966. Un Padina nouveau des côtes d'Afrique: $P a$ dina glabra sp. nova. Phycologia 5:222-226.

Gallagher, S. B. \& Humm, H. J. 1983. Centroceras internitens n. sp. (Rhodophyceae, Ceramiaceae) from the western tropical North Atlantic Ocean. J. Phycol. 19:261-268.

Ganesan, E. K. 1970. A new species of Gelidiocolax Gardner (Choreocolaceae, Rhodophyta) from the Caribbean Sea. Bol. Inst. Oceanogr. Univ. Oriente 9:92-102.

Ganesan, E. K. 1976. On Kallymenia westii sp. nov. (Rhodophyta, Cryptonemiales) from the Caribbean Sea. Bol. Inst. Oceanogr. Univ. Oriente 15:169-175.

Ganesan, E. K. \& Lemus, A. J. 1972. Studies on the marine algal flora of Venezuela. IV. Botryocladia papenfussiana sp. nov. (Rhodophyceae, Rhodymeniales). Phycologia 11:25-31.

Garbary, D. J. \& Harper, J. T. 1998. A phylogenetic analysis of 
the Laurencia complex (Rhodomelaceae) of the red algae. Cryptogam. Algol. 19:185-200.

Gavio, B. \& Fredericq, S. 2003. Botryocladia caraibica (Rhodymeniales, Rhodophyta), a new species from the Caribbean. Cryptogam. Algol. 24:93-106.

Gavio, B. \& Fredericq, S. 2005. New species and new records of offshore members of the Rhodymeniales (Rhodophyta) in the northern Gulf of Mexico. Gulf Mex. Sci. 23:5883.

Gepp, A. \& Gepp, E. S. 1911. The Codiaceae of the Siboga Expedition, including a monograph of Flabellarieae and Udoteae. Siboga-Expeditie Monogr. 62:1-150.

Goreau, T. F. \& Graham, E. A. 1967. A new species of Halimeda from Jamaica. Bull. Mar. Sci. 17:432-441.

Guimarães, S. M. P. B. 2006. A revised checklist of benthic marine Rhodophyta from the State of Espírito Santo, Brazil. Bol. Inst. Bot. 17:143-194.

Guimarães, S. M. P. B. \& Amado-Filho, G. M. 2009. First record of Reticulocaulis mucosissimus I. A. Abbott (Naccariaceae, Rhodophyta) for the western Atlantic Ocean. Rev. Bras. Bot. 32:671-675.

Guimarães, S. M. P. B., Braga, M. R. A., Cordeiro-Marino, M. \& Pedrini, A. G. 1986. Morphology and taxonomy of Jolyna laminarioides, a new member of the Scytosiphonales (Phaeophyceae) from Brazil. Phycologia 25:99-108.

Guimarães, S. M. P. B., Fjii, M. T., Pupo, D. \& Yokoya, N. S. 2004. An assessment of the morphological characteristics and its taxonomical implication in the genus Polysiphonia sensu lato (Ceramiales, Rhodophyta) from the littoral of São Paulo and Espírito Santo States, Brazil. Rev. Bras. Bot. 27:163-183.

Guimarais, M., Cabrera, R. \& Suárez, A. M. 2009a. Adición a las Chlorophyta de Cuba. Rev. Invest. Mar. 30:163-166.

Guimarais, M., Suárez, A. M. \& Cabrera, R. 2009b. Especies de Halimeda, sección Micronesica (Bryopsidales, Halimedaceae) en el Archipélago Jardines de la Reina, SE de Cuba. Rev. Invest. Mar. 30:169-172.

Gurgel, C. F. D. \& Fredericq, S. 2004. Systematics of the Gracilariaceae (Gracilariales, Rhodophyta): a critical assessment based on $r b c \mathrm{~L}$ sequence analysis. J. Phycol. 40:138-159.

Gurgel, C. F. D., Fredericq, S. \& Norris J. N. 2003a. Gracilariopsis silvana sp. nov., G. hommersandii sp. nov., and $G$. cata-luziana sp. nov., three new species of Gracilariaceae (Gracilariales, Rhodophyta) from the western Atlantic. Hydrobiológica 13:57-68.

Gurgel, C. F. D., Fredericq, S. \& Norris J. N. 2004a. Gracilaria apiculata and G. flabelliformis (Gracilariales, Rhodophyta): restoring old names for common tropical western Atlantic species, including the recognition of three new subspecies, and a replacement name for " $G$. lacinulata". Cryptogam. Algol. 25:367-396.

Gurgel, C. F. D., Fredericq, S. \& Norris, J. N. 2004b. Molecular systematics and taxonomy of flattened species of Gracilaria Greville (Gracilariaeae, Gracilariales, Rhodophyta from thre western Atlantic. In Abbott, I. A. \& McDermid, K. J. (Eds.) Taxonomy of Economic Seaweeds with Reference to the Pacific and Other Locations. Vol. IX. Publication of the Hawaii Sea Grant College Program, Report No. UNIHI-Seagrant-CR-0204. University of Hawaii Sea Grant College Program, Honolulu, HI, pp. 159199.

Gurgel, C. F. D., Fredericq, S. \& Norris J. N. 2004c. Phylogeography of Gracilaria tikvahiae (Gracilariaceae, Rhodophyta): a study of genetic discontinuity in a continuously distributed species based on molecular evidence. J. Phycol. 40:748-758.

Gurgel, C. F. D., Fredericq, S., Norris, J. N. \& Yoneshigue-Valentin, Y. 2008. Two new flat species of Gracilaria (Gracilariales, Rhodophyta) from Brazil: G. abyssalis sp. nov. and G. brasiliensis sp. nov. Phycologia 47:249-264.

Gurgel, C. F. D., Liao L. M., Fredericq, S. \& Hommersand, M. H. 2003b. Systematics of Gracilariopsis (Gracilariales, Rhodophyta) based on $r b c$ L sequence analyses and morophological evidence. J. Phycol. 39:154-171.

Hamel, G. 1939. Sur la classification des Ectocarpales. Bot. Not. 1939:65-70.

Hansen, G. I. 1977. Cirrulicarpus carolinensis, a new species in the Kallymeniaceae (Rhodophyta). Occas. Pap. Farlow Herb. Harvard Univ. 12:1-22.

Harvey, W. H. 1853. Nereis boreali-americana. Part II. Rhodospermeae. Smithson. Contrib. Knowledge 5:1-258.

Hayden, H. S., Blomster, J., Maggs, C. A., Silva, P. C., Stanhope, M. J. \& Waaland, J. R. 2003. Linnaeus was right all along: Ulva and Enteromorpha are not distinct genera. Eur. J. Phycol. 38:277-294.

Henne, K. -D. \& Schnetter, R. 1999. Revision of the Pseudobryopsis/Trichosolen complex (Bryopsidales, Chlorophyta) based on features of gametangial behavior and chloroplasts. Phycologia 38:114-127.

Henry, E. C. 1984. Syringodermatales ord. nov. and Syringoderma floridana sp. nov. (Phaeophyceae). Phycologia 23:419-426.

Henry, E. C. 1987. Morphology and life histories of Onslowia bahamensis sp. nov. and Verosphacela ebrachia gen. et sp. nov., with a reassessment of the Choristocarpaceae (Sphacelariales, Phaeophyceae). Phycologia 26:182-191.

Hillis, L. 1959. A revision of the genus Halimeda (order Siphonales). Publ. Inst. Mar. Sci. Univ. Tex. 6:321-403.

Hillis-Colinvaux, L. 1980. Ecology and taxonomy of Halim- 
eda: primary producer of coral reefs. Adv. Mar. Biol. 17:1-327.

Hine, A. E. \& Humm, H. J. 1971. Caulerpa ollivieri in the Gulf of Mexico. Bull. Mar. Sci. 21:552-555.

Hörnig, I. \& Schnetter, R. 1988. Notes on Dictyota dichotoma, D. menstrualis, D. indica and D. pulchella spec. nova (Phaeophyta). Phyton (Austria) 28:277-291.

Hörnig, I., Schnetter, R., Prud'homme van Reine, W. F., Coppejans, E., Achenbach-Wege, K. \& Over, J. M. 1992. The genus Dictyota (Phaeophyceae) in the North Atlantic. I. A new generic concept and new species. Nova Hedwigia 54:45-62.

Hommersand, M. H. \& Freshwater D. W. 2009. Gracilaria hummii sp. nov. (Gracilariales, Rhodophyta), a new name for the agarophyte "Gracilaria confervoides" harvested in North Carolina during World War II. J. Phycol. 45:503-516.

Horta, P. A. \& Oliveira, E. C. 2001. Some Delesseriaceae (Ceramiales, Rhodophyta) new to the southwestern Atlantic. Rev. Bras. Bot. 24:447-454.

Horta, P. A., Yokoya, N. S., Guimarães, S. M. P. B., Bacci, D. S. \& Oliveira, E. C. 2003. Morphology, reproduction and development of Hypoglossum hypoglossoides (Stackhouse) Collins \& Hervey (Ceramiales, Rhodophyta) from the south and southeastern Brazilian coast. Rev. Bras. Bot. 26:453-460.

Howe, M. A. 1917. A note on the structural dimorphism of sexual and tetrasporic plants of Galaxaura obtusata. Contrib. N. Y. Bot. Gard. 193:623-624.

Huerta, M. L. \& Garza, B. A. 1980. Contribución al conocimiento de la flora marina de la zona sur del litoral de Quintana Roo, México. An. Esc. Nac. Cienc. Biol. Mex. 23:25-44.

Huisman, J. M. 1985. The Scinaia assemblage (Galaxauraceae, Rhodophyta): a reappraisal. Phycologia 24:403-418.

Huisman, J. M. 2002. The type and Australian species of the red algal genera Liagora and Ganonema (Liagoraceae, Nemaliales). Aust. Syst. Bot. 15:773-838.

Huisman, J. M., Abbott, I. A. \& Sherwood, A. R. 2004a. The Liagoraceae (Nemaliales, Rhodophyta) of the Hawaiian Islands. III. The genus Ganonema, with a description of G. yoshizakii sp. nov. Phycologia 43:296-310.

Huisman, J. M., Ballantine, D. L. \&Wynne, M. J. 2001 ['2000']. Liagorothamnion mucoides gen. et sp. nov. (Ceramiaceae, Rhodophyta) from the Caribbean Sea. Phycologia 39:507-516.

Huisman, J. M. \& Borowitzka, M. A. 1990. A revision of the Australian species of Galaxaura (Rhodophyta, Galaxauraceae), with a description of Tricleocarpa gen. nov. Phycologia 29:150-172.
Huisman, J. M., Harper, J. T. \& Saunders, G. W. 2004b. Phylogenetic study of the Nemaliales (Rhodophyta) based on large-subunit ribosomal DNA sequences supports segregation of the Scinaiaceae fam. nov. and resurrection of Dichotomaria Lamarck. Phycol. Res. 52:224-234.

Huisman, J. M. \& Kraft, G. T. 1994. Studies of the Liagoraceae (Rhodophyta) of Western Australia: Gloiotrichus fractalis gen. et sp. nov. and Ganonema helminthaxis sp. nov. Eur. J. Phycol. 29:73-85.

Huisman, J. M. \& Millar, A. J. K. 1996. Asteromenia (Rhodymeniaceae, Rhodymeniales), a new red algal genus based on Fauchea peltata. J. Phycol. 32:138-145.

Huisman, J. M., Saunders, G. W. \& Sherwood, A. R. 2006. Recognition of Titanophycus, a new genus based on Liagora valida Harv. (Liagoraceae, Nemaliales). In Huisman, J. M. (Ed.) Algae of Australia: Nemaliales. Australian Biological Resources Study, Canberra; CSIRO Publishing, Melbourne, pp. 116-119.

Huisman, J. M. \& Schils, T. 2002. A re-assessment of the genus Izziella Doty (Liagoraceae, Rhodophyta). Cryptogam. Algol. 23:237-249.

Huisman, J. M. \& Wynne, M. J. 1999. Liagora tsengii sp. nov. (Liagoraceae, Nemaliales) from the Lesser Antilles, West Indies. Bot. Mar. 42:219-225.

Irvine, L. \& Steentoft, M. 1995. Proposal to reject the name Fucus verrucosa Huds. (Rhodophyta). Taxon 44:223-224.

Itono, H. \& Tanaka, T. 1973. Balliella, a new genus of Ceramiaceae (Rhodophyta). Bot. Mag. Tokyo 86:241-252.

Jaasund, E. 1970. Marine algae in Tanzania II. Bot. Mar. 13:59-64.

Joly, A. B. 1966. Centrocerocolax, a new parasitic genus of the Rhodophyta. Rickia 2:73-79.

Joly, A. B., Cordeiro-Marino, M., Ugadim, Y., Yamaguishi-Tomita, N. \& Pinheiro, F. C. 1965. New marine algae from Brazil. Arq. Estac. Biol. Mar. Univ. Ceara 5:79-92.

Joly, A. B., Cordeiro, M., Yamaguishi, N. \& Ugadim, Y. 1966 ['1965']. New marine algae from southern Brazil. Rickia 2:159-181.

Joly, A. B. \& Oliveira Filho, E. C. de. 1966. Spyridiocolax and Heterodasya, two new genera of the Rhodophyceae. Sellowia 18:115-125.

Joly, A. B. \& Oliveira Filho, E. C. de. 1967. Two Brazilian Laminarias. Publ. Inst. Pesqui. Mar. Rio J. 4:1-13.

Joly, A. B. \& Oliveira Filho, E. C. de. 1968. Notes on Brazilian algae. II. A new Anadyomene of the deep water flora. Phykos 7:27-31.

Joly, A. B., Oliveira Filho, E. C. de, Ugadim, Y., Pinheiro, F. C., Ferreira, M. M. \& Cordeiro-Marino, M. 1968. Additions to the marine flora of Brazil- VIII. Rickia 3:161-170.

Joly, A. B. \& Pereira, S. M. B. 1973. A new Anadyomene from 
the tropical American South Atlantic. Bol. Bot. Univ. (São Paulo) 1:79-83.

Joly, A. B. \& Pereira, S. M. B. 1975. Caulerpa kempfii Joly et Pereira, a new Caulerpa from northeastern Brazil. Cienc. Cult. (São Paulo) 27:417-419.

Joly, A. B. \& Sazima, M. 1971. Brazilian deep-water marine algae. Additions to the Brazilian flora. Cienc. Cult. (São Paulo) 23:333-336.

Joly, A. B., Ugadim, Y. \& Oliveira Filho, E. de. 1967. The structure and reproduction of Periphykon delesserioides a new member of the Rhodomelaceae. Sellowia 19:71-78.

Joly, A. B. \& Yamaguishi-Tomita, N. 1967. Dawsoniocolax bostrychiae a new parasite on mangrove algae. Sellowia 19:63-70.

Joly, A. B. \& Yamaguishi-Tomita, N. 1970 ['1969']. Note on Dawsoniella Joly \& Yamaguishi-Tomita. Rickia 4:209210.

Kawai, H., Hanyuda, T., Draisma, S. G. A. \& Müller, D. G. 2007. Molecular phylogeny of Discosporangium mesarthrocarpum (Phaeophyceae) with a reinstatement of the order Discosporangiales. J. Phycol. 43:186-194.

Kilar, J. A. 1992. Seasonal and between-plant variability in the morphology of Sargassum mathiesonii sp. nov. (Phaeophyta) from the Gulf of Mexico. J. Phycol. 28:114-126.

Kim, M. S. \& Lee, I. K. 1999. Neosiphonia flavimarina gen. et sp. nov. with a taxonomic reassessment of the genus Polysiphonia (Rhodomelaceae, Rhodophyta). Phycol. Res. 47:271-281.

Kjellman, F. R. 1900. Om floride-slagtet Galaxaura dess organografi och systematik. Kungl. Sven. Vetenskaps. Handl. 33:1-109.

Knoepffler-Péguy, M. 1970. Quelques Feldmannia Hamel 1939 (Phaeophyceae-Ectocarpales) des côtes d'Europe. Vie Milieu Sér. A Biol. Mar. 21:137-188.

Kooistra, W. H. C. F. \& Verbruggen, H. 2005. Genetic patterns in the calcified tropical seaweeds Halimeda opuntia, $H$. distorta, H. hederacea, and H. minima (Bryopsidales, Chlorophyta) provide insights in species boundaries and interoceanic dispersal. J. Phycol. 41:177-187.

Kraft, G. T. 1984. The red algal genus Predaea (Nemastomataceae, Gigartinales) in Australia. Phycologia 23:3-20.

Kraft, G. T. \& Wynne, M. J. 1996. Delineation of the genera Struvea Sonder and Phyllodictyon J. E. Gray (Cladophorales, Chlorophyta). Phycol. Res. 44:129-142.

Krauss, F. 1846. Pflanzen des Cap- und Natal-Landes, gesammelt und zusammengestellt von Dr. Ferdinand Krauss. (Schluss). Flora 29:209-219.

Kuckuck, P. 1956. Ectocarpaceen-Studien. IV. Herponema, Kützingiella nov. gen., Farlowiella nov. gen. (edited by P. Kornmann). Helgolander Wiss. Meeresunters. 5:292-
325.

Kützing, F. T. 1863. Diagnosen und Bemerkungen zu drei und siebenzig neuen Algenspecies. Zu der öffentlichen Prüfung sämmtlicher Klassen der Realschule zu Nordhausen, Nordhausen, $19 \mathrm{pp}$.

Kylin, H. 1947. Über die Fortpflanzungsverhältnisse in der Ordnung Ulvales. Kungl. Fysiogr. Sällsk. Lund Förhand.17:174-182.

Lam, D. W. \& Zechman, F. W. 2006. Phylogenetic analyses of the Bryopsidales (Ulvophyceae, Chlorophyta) based on rubisco large subunit gene sequences. J. Phycol. 42:669678.

Lapointe, B. E., Barile, P. J., Wynne, M. J. \&Yentsch, C. S. 2005. Reciprocal invasion: Mediterranean native Caulerpa ollivieri in the Bahamas supported by human nitrogen enrichment. Aquat. Invaders 16:1, 3-5.

Le Gall, L., Dalen, J. L. \& Saunders, G. W. 2008. Phylogenetic analyses of the red algal order Rhodymeniales supports recognition of the Hymenocladiaceae fam. nov., Fryeellaceae fam. nov., and Neogastroclonium gen. nov. J. Phycol. 44:1556-1571.

Le Gall, L. \& Saunders, G. W. 2007. A nuclear phylogeny of the Florideophyceae (Rhodophyta) inferred from combined EF2, small subunit and large subunit ribosomal DNA: establishing the new red algal subclass Corallinophycidae. Mol. Phylogenet. Evol. 43:1118-1130.

L'Hardy-Halos, M. -Th. \& Rueness, J. 1990. Comparative morphology and crossability of related species of Aglaothamnion (Rhodophyta). Phycologia 29:351-366.

Lim, P. -E., Sakaguchi, M., Hanyuda, T., Kogame, K., Phang, S. -M. \& Kawai, H. 2007. Molecular phylogeny of crustose brown algae (Ralfsiales, Phaeophyceae) inferred from $r b c \mathrm{~L}$ sequences resulting in the proposal for Neoralfsiaceae fam. nov. Phycologia 46:456-466.

Lin, S. -M., Fredericq, S. \& Hommersand, M. H. 2004. Augophyllum, a new genus of the Delesseriaceae (Rhodophyta) based on $r b c \mathrm{~L}$ sequence analysis and cystocarp development. J. Phycol. 40:962-976.

Littler, D. S. \& Littler, M. M. 1990a. Reestablishment of the green algal genus Rhipidosiphon Montagne (Udoteaceae, Bryopsidales) with a description of Rhipidosiphon floridensis sp. nov. Br. Phycol. J. 25:33-38.

Littler, D. S. \& Littler, M. M. 1990b. Systematics of Udotea species (Bryopsidales, Chlorophyta) in the tropical western Atlantic. Phycologia 29:206-252.

Littler, D. S. \& Littler, M. M. 1991. Systematics of Anadyomene species (Anadyomenaceae, Chlorophyta) in the tropical western Atlantic. J. Phycol. 27:101-118.

Littler, D. S. \& Littler, M. M. 1992. Systematics of Avrainvillea (Bryopsidales, Chlorophyta) in the tropical western 
Atlantic. Phycologia 31:375-418.

Littler, D. S. \& Littler, M. M. 2000. Caribbean reef plants: an identification guide to the reef plants of the Caribbean, Bahamas, Florida, and Gulf of Mexico. OffShore Graphics, Ltd.,Washington, DC, 542 pp.

Lozada-Troche, C. \& Ballantine, D. L. 2010. Champia puertoricensis sp. nov. (Rhodophyta: Champiaceae) from Puerto Rico, Caribbean Sea. Bot. Mar. 53:131-141.

Lozada-Troche, C., Ballantine, D. L. \& Ruíz, H. 2010. Cresia opalescens gen. et sp. nov. (Rhodymeniaceae, Rhodophyta) from Puerto Rico, Caribbean Sea. Cryptogam. Algol. 31:293-303.

Lukas, K. J. 1974. Two species of the chlorophyte genus Ostreobium from skeletons of Atlantic and Caribbean reef corals. J. Phycol. 10:331-335.

MacRaild, G. N. \&Womersley, H. B. S. 1974. The morphology and reproduction of Derbesia clavaeformis (J. Agardh) De Toni (Chlorophyta). Phycologia 13:83-93.

Maggs, C. A., Guiry, M. D. \& Rueness, J. 1991. Aglaothamnion priceanum sp. nov. (Ceramiaceae, Rhodophyta) from the north-eastern Atlantic: morphology and life history of parasporangial plants. Br. Phycol. J. 26:343-352.

Maggs, C. A., Verbruggen, H. \& De Clerck, O. 2007. Molecular systematics of red algae: building future strutures on firm foundations. In Brodie, J. \& Lewis, J. (Eds.) Unraveling the Algae: the Past, Present and Future of Algal Systematics. Systematics Association Special Vol. Ser. 75. CRC Press, Boca Raton, FL, pp. 103-121.

Marcot-Coqueugniot, J. 1988. Sur quelques Peyssonneliaeaeae (Rhodophyceae) récoltées en profondeur au large côtes du Bresil. Vie Milieu, Sér. A Biol. Mar. 38:299-309.

Martínez-Daranas, B., Díaz, J. \& Esquivel, M. 2002. Nuevos registros de algas marinas cubanas (II). New reports of Cuban marine algae (II). Avicennia 15:147-149.

Martin-Lescanne, J., Rousseau, F., Reviers, B. de, Payri, C., Couloux, A., Cruaud, C. \& Le Gall, L. 2010. Phylogenetic analyses of the Laurencia complex (Rhodomelaceae, Ceramiales) support recognition of five genera: Chondrophycus, Laurencia, Osmundea, Palisada and Yuzurua stat. nov. Eur. J. Phycol. 45:51-61.

Mateo-Cid, L. E., Mendoza-González, A. C. \& Searles, R. B. 2002. New Mexican records of marine algae including Crouania mayae sp. nov. (Ceramiaceae, Rhodophyta). Caribb. J. Sci. 38:205-221.

McLachlan, J. 1979. Gracilaria tikvahiae sp. nov. (Rhodophyta, Gigartinales, Gracilariaceae), from the northwestern Atlantic. Phycologia 18:19-23.

Montagne, C. 1861 ['1860']. Heutième centurie de plantes cellulaires nouvelles tant indigènes qu'exotiques. Decades I, II. Ann. Sci. Nat. Bot. Sér. 4 14:167-185.
Morrill, J. 1976. Notes on parasitic Rhodomeladeae. III. Meridiocolax narcissus, a new red alga parasitic on Polysiphonia ferulacea Suhr from the Florida Keys. Proc. Acad. Nat. Sci. Phila. 127:233-248.

Müller, D. G., Parodi, E. R. \& Peters, A. F. 1999 ['1998']. Asterocladon lobatum gen. et sp. nov., a new brown alga with stellate chloroplast arrangement, and its systemic position judged from nuclear rDNA sequences. Phycologia 37:425-432.

Müller, K. M., Cannone, J. J. \& Sheath, R. G. 2005. A molecular phylogenetic analysis of the Bangiales (Rhodophyta) and description of a new genus and species, Pseudobangia kaycoleia. Phycologia 44:146-155.

Nam, K. W. 1999. Morphology of Chondrophycus undulata and C. parvipapillata and its implications for the taxonomy of the Laurencia (Ceramiales, Rhodophyta) complex. Eur. J. Phycol. 34:455-468.

Nam, K. W. 2006. Phylogenetic re-evaluation of the Laurencia complex (Rhodophyta) with a description of $L$. succulenta sp. nov. from Korea. J. Appl. Phycol. 18:679-697.

Nam, K. W. 2007. Validation of the generic name Palisada (Rhodomelaceae, Rhodophyta). Algae 22:53-55.

Nam, K. W., Maggs, C. A. \& Garbary, D. J. 1994. Resurrection of the genus Osmundea with an emendation of the generic delineation of Laurencia (Ceramiales, Rhodophyta). Phycologia 33:384-395.

Neefus, C. D., Mathieson, A. C., Bray, T. L. \& Yarish, C. 2008. The distribution, morphology, and ecology of three introduced Asiatic species of Porphyra (Bangiales, Rhodophyta) in the northwestern Atlantic. J. Phycol. 44:1399-1414.

Norris, J. N. \& Ballantine, D. L. 1995. Two new species of the red alga Chrysymenia J. Agardh (Rhodymeniales: Rhodymeniaceae) from the tropical western Atlantic. Proc. Biol. Soc. Wash. 108:153-165.

Norris, J. N. \& Bucher, K. E. 1989. Rhodogorgon, an anamolous [sic] new red algal genus from the Caribbean Sea. Proc. Biol. Soc. Wash. 102:1050-1066.

Norris, J. N. \& Olsen, J. L. 1991. Deep-water green algae from the Bahamas, including Cladophora vandenhoekii sp. nov. (Cladophorales). Phycologia 30:315-328.

Norris, R. E. 1985. Studies on Pleonosporium and Mesothamnion (Ceramiaceae, Rhodophyta) with a description of a new species from Natal. Br. Phycol. J. 20:59-68.

Norris, R. E. 1987. The systematic position of Gelidiopsis and Ceratodictyon (Gigartinales, Rhodophyceae) genera new to South Africa. S. Afr. J. Bot. 53:239-246.

Okamura, K. 1901. Illustrations of the marine algae of Japan. Vol. 1. Keigyosha, Tokyo, pp. 15-74, pls. VI-XXV.

Oliveira Filho, E. C. de. 1969. Algas marinhas do sul do Es- 
tado do Espírito Santo (Brasil) I. Ceramiales. Bol. Fac. Filos. Ciênc. Let. Univ. São Paulo Bot. 26:1-278.

Oliveira Filho, E. C. de. 1977. Algas marinhas bentonicas do Brasil. Ph.D. dissertation, Universidade de São Paulo, São Paulo, Brazil, 407 pp.

Oliveira Filho, E. C. de, Bird, C. J. \& McLachlan, J. 1983. The genus Gracilaria (Rhodophyta, Gigartinales) in the western Atlantic: Gracilaria domingensis, G. cervicornis, and G. ferox. Can. J. Bot. 61:2999-3008.

Oliveira Filho, E. C. de \& Braga, Y. Y. 1971. A new species of Dasya from Brazil. Cienc. Cult. (São Paulo) 23:605-608.

Oliveira Filho, E. C. de \& Coll, J. 1975. The genus Porphyra C. Ag. (Rhodophyta-Bangiales) in the American South Atlantic. I. Brazilian species. Bot. Mar. 18:191-197.

Oliveira Filho, E. C. de \& Furtado, R. P. 1978. Dictyopteris jolyana sp. nova (Phaeophyta) from Brazil. Nova Hedwigia 29:759-763.

Oliveira Filho, E. C. de, Pinheiro-Vieira, F. \& Norris, R. E. 1976. A new species of Halymenia (Rhodophyta, Cryptonemiaceae) from Brazil. Cienc. Cult. 28:562-565.

Oliveira Filho, E. C. de \& Ugadim, Y. 1974. New references of benthic marine algae to the Brazilian flora. Bol. Bot. Univ. São Paulo 2:71-91.

Oltmanns, F. 1904. Morphologie und biologie der algen. Vol. 1.Verlag von Gustav Fischer, Jena, 733 pp.

Papenfuss, G. F., Mshigeni, K. E. \& Chiang, Y. -M. 1982. Revision of the red algal genus Galaxaura with special reference to the species occurring in the western Indian Ocean. Bot. Mar. 25:401-444.

Peters, A. F. \& Ramírez, M. E. 2001. Molecular phylogeny of small brown algae, with special reference to the systematic position of Caepidium antarcticum (Adenocystaceae, Ectocarpales). Cryptogam. Algol. 22:187-200.

Phillips, N., Burrowes, R., Rousseau, F., Reviers, B. de \& Saunders, G. W. 2008. Resolving evolutionary relationships among the brown algae using chloroplast and nuclear genes. J. Phycol. 44:394-405.

Pinheiro, F. C. \& Joly, A. B. 1966. The sexual male plants of Gracilaria cearensis (Joly et Pinheiro) Joly et Pinheiro. Arq. Estac. Biol. Mar. Univ. Fed. Ceara 6:131-134.

Pinheiro-Joventino, F. \& Oliveira Filho, E. C. de. 1977. A new species of Cryptonemia from Brazil. Arq. Cienc. Mar. 17:49-51.

Plastino, E. M. \& Oliveira, E. C. de. 1996. Approaches to the identification of terete Brazilian Gracilariaceae (Gracilariales, Rhodophyta). Hydrobiologia 326/327:145-148.

Plastino, E. M. \& Oliveira, E. C. de. 1997. Gracilaria caudata J. Agardh (Gracilariales, Rhodophyta): restoring an old name for a common western Atlantic alga. Phycologia 36:225-232.
Plastino, E. M. \& Oliveira, E. C. de. 2002. Gracilaria birdiae (Gracilariales, Rhodophyta), a new species from the tropical South American Atlantic with a terete frond and deep spermatangial conceptacles. Phycologia 41:389396.

Pröschold, T. \& Leliaert, F. 2007. Systematics of the green algae: conflict of classic and modern approaches. In Brodie, J. \& Lewis, J. (Eds.) Unraveling the Algae: the Past, Present, and Future of Algal Systematics. Systematics Association Special Vol. Ser. 75. CRC Press, Boca Raton, FL, pp. 123-153.

Prud'homme van Reine, W. F. \& Lokhorst, G. M. 1992. Caulerpella gen. nov. a non-holocarpic member of the Caulerpales (Chlorophyta). Nova Hedwigia 54:113-126.

Pueschel, C. W. \& Saunders, G. W. 2009. Ramicrusta textilis sp. nov. (Peyssonneliaceae, Rhodophyta), an anatomically complex Caribbean alga that overgrows corals. Phycologia 48:480-491.

Reviers, B. de, Rousseau, F. \& Draisma, S. G. A. 2007. Classification of the Phaeophyceae from past to present and current challenges. In Brodie, J. \& Lewis, J. (Eds.) Unravelling the Algae: the Past, Present, and Future of Algal Systematics. Systematics Association Special Vol. Ser. 75. CRC Press, Boca Raton, FL, pp. 267-284.

Ritzmann, N. F., Salles, J. P., Bouzon, Z. L. \& Horta, P. A. 2007. Dasya rigidula (Ceramiales, Rhodophyta) in the south and southeastern Brazilian coast. Insula 36:7-20.

Rocha-Jorge, R., Cassano, V., Oliveira, M. C. \& Fujii, M. T. 2010. The occurrence of Laurencia marilzae (Ceramiales, Rhodophyta) in Brazil based on morphological and molecular data. Bot. Mar. 53:143-152.

Rodríguez de Rios, N. 1981. Dos especies nuevas de Laurencia (Rhodophyta, Ceramiales). Ernstia 2:1-11.

Rodríguez de Rios, N. 1986. El genero Polycavernosa Chang y Xia (Gracilariaceae, Rhodophyta) en Venezuela, con descripción de una nueva especie. Ernstia 38:12-31.

Rodríguez de Rios, N. \& Lobo, M. 1984. Dos adiciones para la flora de algas marinas de Venezuela. Ernstia 25:1-7.

Rodríguez de Rios, N. \& Saito, Y. 1982. Observaciones sobre el género Laurencia en Venezuela. I. Laurencia intermedia Yamada y Laurencia corallopsis (Montagne) Howe. Ernstia 11:1-16.

Rousseau, F., Burrowes, R., Peters, A. F., Kuhlenkamp, R. \& Reviers, B. de. 2001. A comprehensive phylogeny of the Phaeophyceae based on nrDNA sequences resolves the earliest divergences. C. R. Acad. Sci. Ser. III Sci. Vie 324:305-319.

Rueness, J. 2005. Life history and molecular sequences of Gracilaria vermiculophylla (Gracilariales, Rhodophyta), a new introduction to European waters. Phycologia 
44:120-128.

Rueness, J. \& L'Hardy-Halos, M. -Th. 1991. Aglaothamnion westbrookiae sp. nov. (Rhodophyta), a species previously confused under the name Callithamnion byssoides. J. Phycol. 27:649-652.

Rueness, J. \& Rueness, M. 1980. Culture and field observations on Callithamnion bipinnatum and C. byssoides (Rhodophyta, Ceramiales) from Norway. Sarsia 65:2934.

Saito, Y. 1967. Studies on Japanese species of Laurencia, with special reference to their comparative morphology. Mem. Fac. Fish. Hokkaido Univ. 15:1-81.

Saito, Y. \& Womersley, H. B. S. 1974. The southern Australian species of Laurencia (Ceramiales: Rhodophyta). Aust. J. Bot. 22:815-874.

Santelices, B. 2004. Parviphycus, a new genus in the Gelidiellaceae (Gelidiales, Rhodophyta). Cryptogam. Algol. 25:313-326.

Santelices, B. \& Hommersand, M. 1997. Pterocladiella, a new genus in the Gelidiaceae (Gelidiales, Rhodophyta). Phycologia 36:114-119.

Saunders, G. W., Lane, C. E., Schneider, C. W. \& Kraft, G. T. 2006. Unraveling the Asteromenia peltata species complex with clarification of the genera Halichrysis and Drouetia (Rhodymeniaceae, Rhodophyta). Can. J. Bot. 84:1581-1607.

Schils, T., De Clerck, O. \& Coppejans, E. 2003. The red algal genus Reticulocaulis from the Arabian Sea, including $R$. obpyriformis sp. nov., with comments on the family Naccariaceae. Phycologia 42:44-55.

Schneider, C. W. 1974. North Carolina marine algae. III. A community of Ceramiales (Rhodophyta) on a glass sponge from 60 meters. Bull. Mar. Sci. 24:1093-1101.

Schneider, C. W. 1980. North Carolina marine algae. VIII. The reproductive morphology of Callithamnion cordatum Børgesen (Rhodophyta, Ceramiaceae). Rhodora 82:321330.

Schneider, C. W. 1988. Craspedocarpus humilis sp. nov. (Cystocloniaceae, Gigartinales) from North Carolina, and a reappraisal of the genus. Phycologia 27:1-9.

Schneider, C. W. 1989. Two new species of Dasysiphonia (Dasyaceae, Rhodophyta) from the southeastern United States (Carolinas). Bot. Mar. 32:521-526.

Schneider, C. W. 2000. Notes on the marine algae of the Bermudas. 5. Some Delesseriaceae (Ceramiales, Rhodophyta), including the first record of Hypoglossum barbatum Okamura from the Atlantic Ocean. Bot. Mar. 43:455-466.

Schneider, C. W. 2004. Notes on the marine algae of the Bermudas. 6. Some rare or newly reported Ceramiales (Rhodophyta), including Crouania elisiae sp. nov. Phy- cologia 43:563-578.

Schneider, C. W. \& Eiseman, N. J. 1979. Searlesia, a new genus from the western Atlantic based on Membranoptera subtropica (Rhodophyta, Delesseriaceae). Phycologia 18:319-324.

Schneider, C. W. \& Lane, C. E. 2008. Notes on the marine algae of the Bermudas. 9. The genus Botryocladia (Rhodophyta, Rhodymeniaceae), including $B$. bermudana, $B$. exquisita and B. flookii spp. nov. Phycologia 47:614-629.

Schneider, C. W., Lane, C. E. \& Saunders, G. W. 2006. Crassitegula walsinghamii (Sebdeniaceae, Halymeniales), a new red algal genus and species from Bermuda based upon morphology and SSU rDNA sequence analyses. Eur. J. Phycol. 41:115-124.

Schneider, C. W., Lane, C. E. \& Saunders, G. W. 2010. Notes on the marine algae of the Bermudas. 11. More additions to the benthic flora and a phylogenetic assessment of Halymenia pseudofloresii (Halymeniales, Rhodophyta) from its type locality. Phycologia 49:154-168.

Schneider, C. W. \& Reading, R. P. 1987. A revision of the genus Peyssonnelia (Rhodophyta, Cryptonemiales) from North Carolina, including P. atlantica new species. Bull. Mar. Sci. 40:175-192.

Schneider, C. W. \& Searles, R. B. 1975. North Carolina marine algae. IV. Further contributions from the continental shelf, including two new species of Rhodophyta. Nova Hedwigia 26:83-103.

Schneider, C. W. \& Searles, R. B. 1976. North Carolina marine algae. VII. New species of Hypnea and Petroglossum (Rhodophyta, Gigartinales) and additional records of other Rhodophyta. Phycologia 15:51-60.

Schneider, C. W. \& Searles, R. B. 1997. Notes on the marine algae of the Bermudas. 1. New records of Antithamnieae and Dohrnielleae (Ceramiaceae, Rhodophyta), including Antithamnionella bermudica sp. nov. Phycologia 36:12-23.

Schneider, C. W. \& Searles, R. B. 1998. Notes on the marine algae of the Bermudas. 4. Additions to the flora, including Polysiphonia plectocarpa sp. nov. Phycologia 37:24-33.

Schneider, C. W. \& Wynne, M. J. 2009 ['2008']. Notes on the marine algae of the Bermudas. 10. Woelkerlingia sterreri sp. nov. (Rhodophyta, Wrangeliaceae), a first record of the genus in the western Atlantic. Caribb. J. Sci. 44:303310 .

Schnetter, R. 1972. Nuevas algas bénthicas del littoral Caribe de Colombia. Mutisia 36:12-16.

Schnetter, R. 1975. Nuevas algas benticas del litoral Caribe de Colombia. Caldasia 11:57-60.

Schnetter, R. 1978. Botryocladia monoica (Rhodymeniales, Rhodophyceae), a new species from the Caribbean 
coast of Colombia. Phycologia 17:13-15.

Schnetter, R., Hörnig, I. \&Weber-Peukert, G. 1987. Taxonomy of some North Atlantic Dictyota species (Phaeophyta). Hydrobiologia 151/152:193-197.

Schnetter, R. \& Richter, U. 1979. Systematische Stellung und Vorkommen einer Corallinoidee (Corallinaceae, Cryptonemiales, Rhodophyceae) aus der Karibischen. Ber. Dtsch. Bot. Ges. 92:455-466.

Schnetter, R., Richter, A., Schesmer, A. \& Bula, M. G. 1983. Licht- und elektronenmikroskopische Untersuchungen an Grateloupiocolax colombiana gen. et spec. nov. (Halymeniaceae, Rhodophyceae). Beitr. Biol. Pflanz. 58:77-94.

Scott, J. L., Baca, B., Ott, F. D. \& West, J. A. 2006. Light and electron microscopic observations on Erythrolobus coxiae gen. et sp. nov. (Porphyrideophyceae, Rhodophyta) from Texas U.S.A. Algae 21:407-416.

Searles, R. B. 1972. North Carolina marine algae. I. Three new species of the continental shelf. Phycologia 11:19-24.

Searles, R. B. 1981. Seaweeds from Gray's Reef, Georgia. Northeast Gulf Sci. 5:45-48.

Searles, R. B. 1983. Vegetative and reproductive morphology of Dudresnaya georgiana sp. nov. (Rhodophyta, Dumontiaceae). Phycologia 22:309-316.

Searles, R. B. \& Ballantine, D. L. 1986. Dudresnaya puertoricensis sp. nov. (Dumontiaceae, Gigartinales, Rhodophyta). J. Phycol. 22:389-394.

Searles, R. B. \& Leister, G. L. 1980. North Carolina marine algae. IX. Onslowia endophytica gen. et sp. nov. (Phaeophyta, Sphacelariales) and notes on other new records for North Carolina. J. Phycol. 16:35-40.

Searles, R. B. \& Lewis, S. M. 1983. North Carolina marine algae. XI. A new species of Helminthocladia (Liagoraceae, Nemaliales, Rhodophyta) with a reappraisal of the generic limits of Helminthocladia and Helminthora. J. Phycol. 19:164-172.

Searles, R. B. \& Schneider, C. W. 1989. New genera and species of Ceramiaceae (Rhodophyta) from the southeastern United States. J. Phycol. 25:731-740.

Sears, J. R. \& Brawley, S. H. 1982. Smithsoniella gen. nov., a possible evolutionary link between the multicellular and siphonous habits in the Ulvophyceae, Chlorophyta. Am. J. Bot. 69:1450-1461.

Sentíes, A., Areces, A., Díaz-Larrea, J. \& Fujii, M. T. 2010. First records of Laurencia caduciramulosa and L. minuscula (Ceramiales, Rhodophyta) from the Cuban archipelago. Bot. Mar. 53:433-438.

Sentíes, A. \& Díaz-Larrea, J. 2008. Proposals for Palisada poiteaui var. gemmifera comb. nov. and Palisada corallopsis comb. nov. (Rhodomelaceae, Rhodophyta). Bot. Mar.
51:69-70.

Sentíes, A., Díaz-Larrea, J., Cassano, V., Gil-Rodríguez, M. C. \& Fujii, M. T. 2011. Laurencia marilzae (Ceramiales, Rhodophyta) from the Mexican Caribbean: a new record for the tropical western Atlantic. Bull. Mar. Sci. DOI: 10.5343/bms.2010.1094.

Sentíes, G. A., Fujii, M. T. \& Rodríguez, D. 2001. Laurencia venusta (Ceramiales, Rhodophyta): a new record from the Atlantic Ocean. Bot. Mar. 44:95-99.

Serio, D., Petrocelli, A., Cormaci, M., Cecere, E. \& Furnari, G. 2008. First record of Osmundea oederi (Gunnerus) G. Furnari comb. nov. (Rhodomelaceae, Rhodophyta) from the Mediterranean Sea. Cryptogam. Algol. 29:119-127.

Setchell, W. A. 1926. Tahitian algae collected by W.A. Setchell, C. B. Setchell, and H. E. Parks. Univ. Calif. Publ. Bot. 12:61-142.

Silva, P. C. 1972. Remarks on algal nomenclature V. Taxon 21:199-205.

Silva, P. C., Basson, P. W. \& Moe, R. L. 1996. Catalogue of the benthic marine algae of the Indian Ocean. Univ. Calif. Publ. Bot. 79:1-1259.

Sonder, O. W. 1855. Algae annis 1852-1853 collectae. Linnaea 26:506-528.

Stackhouse, J. 1809. Tentamen marino-cryptogamicum. Mém. Soc. Imp. Nat. Moscou 2:50-97.

Steentoft, M., Irvine, L. M. \& Farnham, W. F. 1995. Two terete species of Gracilaria and Gracilariopsis (Gracilariales, Rhodophyta) in Britain. Phycologia 34:113-127.

Stegenga, H. \& Vroman, M. 1986. Pterocladiophila hemisphaerica (Rhodophyta, Cryptonemiales) in the Caribbean. Acta Bot. Neerl. 35:1-4.

Stuercke, B. \& Freshwater, D. W. 2008. Consistency of morphological characters used to delimit Polysiphonia sensu lato species (Ceramiales, Florideophyceae): analyses of North Carolina, USA specimens. Phycologia 47:541559.

Stuercke, B. \& Freshwater, D. W. 2010. Two new species of Polysiphonia (Ceramiales, Florideophyceae) from the western Atlantic. Bot. Mar. 53:301-311.

Taylor, W. R. 1950. Plants of Bikini and other northern Marshall Islands. University of Michigan Press, Ann Arbor, MI, 227 pp.

Taylor, W. R. 1960. Marine algae of the eastern tropical and subtropical coasts of the Americas. University of Michigan Press, Ann Arbor, MI, 870 pp.

Taylor, W. R. 1961. Notes on three Bermudian marine algae. Hydrobiologia 18:277-283.

Taylor, W. R. 1962a. A note on Bryopsis in the West Indies. Phycologia 2:24-28.

Taylor, W. R. 1962b. Marine algae from the tropical Atlantic 
Ocean. V. Algae from the lesser Antilles. Contrib. U. S. Natl. Herb. 36:43-62.

Taylor, W. R. 1962c. Observations on Pseudobryopsis and Trichosolen (Chlorophyceae-Bryopsidaceae) in America. Brittonia 14:58-65.

Taylor, W. R. 1962d. Two undescribed species of Halimeda. Bull. Torrey Bot. Club 89:172-177.

Taylor, W. R. 1971. A new Naccaria from the West Indies. Hydrobiologia 38:207-212.

Taylor, W. R. 1974. Notes on algae from the tropical Atlantic Ocean. VII. Rev. Algol. Nouv. Ser. 11:58-71.

Taylor, W. R. 1975. A pelagic Sargassum from the western Atlantic. Contrib. Univ. Mich. Herb. 11:73-75.

Taylor, W. R. \& Abbott, I. A. 1973. A new species of Botryocladia from the West Indies. Br. Phycol. J. 8:409-412.

Thomsen, M. S., Gurgel, C. F. D., Fredericq, S. \& McGlathery, K. J. 2006. Gracilaria vermiculophylla (Rhodophyta, Gracilariales) in Hog Island Bay, Virginia: a cryptic alien and invasive macroalga and taxonomic correction. J. Phycol. 42:139-141.

Tseng, C. K. 1981. Commercial cultivation. In Lobban, C. S. \&Wynne, M. J. (Eds.) The Biology of Seaweeds. Botanical Monographs Vol. 17. Blackwell Scientific Publications, Oxford, pp. 680-725.

van den Hoek, C. 1969. Notes on Cladophora (Chlorophyceae). I. Two new Caribbean species: Cladophora jongiorum nov. sp. and Cladophora longicellulata nov. sp. J. Phycol. 5:128-134.

van den Hoek, C. 1978. Marine algae from the coral reef of Curaçao, Netherlands Antilles. I. Three new and one rarely observed species from the steep fore-reef slope. Aquat. Bot. 5:47-61.

van den Hoek, C. 1982. A taxonomic revision of the American species of Cladophora (Chlorophyceae) in the North Atlantic Ocean and their geographic distribution. NorthHolland Publishing Co., Amsterdam, 236 pp.

van den Hoek, C. \& Rios, N. de. 1972. Willeella ordinata Boergesen, 1930 (Chlorophyceae, Cladophoraceae): first record for America. J. Phycol. 8:207-208.

van den Hoek, C. \& Searles, R. B. 1988. Cladophora pseudobainesii nov. spec. (Chlorophyta): an addition to the N. W. Atlantic species of Cladophora. Bot. Mar. 31:521-524.

Vélez, S. M. \& Vega, R. M. 2005. Helminthora anomala sp. nov. (Liagoraceae, Rhodophyta) from Puerto Rico. Caribb. J. Sci. 41:834-842.

Verbruggen, H., De Clerck, O., Cocquyt, E., Kooistra, W. H. C. F. \& Coppejans, E. 2005. Morphometric taxonomy of siphonous green algae: a methodological study within the genus Halimeda (Bryopsidales). J. Phycol. 41:126-139.

Verbruggen, H., Leliaert, F., Maggs, C. A., Shimada, S., Schils,
T., Provan, J., Booth, D., Murphy, S., De Clerck, O., Littler, D. S., Littler, M. M. \& Coppejans, E. 2007a. Species boundaries and phylogenetic relationships within the green algal genus Codium (Bryopsidales) based on plastid DNA sequences. Mol. Phylogenet. Evol. 44:240-254.

Verbruggen, H., Littler, D. S. \& Littler, M. M. 2007b. Halimeda pygmaea and Halimeda pumila (Bryopsidales, Chlorophyta): two new dwarf species from fore reef slopes in Fiji and the Bahamas. Phycologia 46:513-520.

Vickers, A. 1908. Phycologia barbadensis. Iconographie des algues marines récoltées à I'ile Barbade (Antilles) (Chlorophycées et Phéophycées). Avec texte explicatif par $M$. H. Shaw. Libraire des Sciences naturelles, Klincksieck, Paris, 44 pp.

Villas-Boas, A. B., Riosmena-Rodriguez, R., Amado-Filho, G. M., Maneveldt, G. W. \& Figueiredo, M. A. O. 2009. Rhodolith-forming species of Lithophyllum (Corallinales; Rhodophyta) from Espírito Santo State, Brazil, including the description of $L$. depressum sp. nov. Phycologia 48:237-248.

Vinogradova, K. L. 1969. A contribution to the systematics of the order Ulvales (Chloropyta). Bot. Zh. SSSR 54:13471355 (in Russian with English summary).

Vroman, M. 1967. A new species of Stichothamnion (Rhodophyta) from the West Indies. Acta Bot. Neerl. 15:557561.

Wang, W. -L., Liu, S. -L. \& Lin, S. -M. 2005. Systematics of the calcified genera of the Galaxauraceae (Nemaliales, Rhodophyta) with an emphasis on Taiwan species. J. Phycol. 41:685-703.

Weber van Bosse, A. 1913. Marine algae, Rhodophyceae, of the "Sealark" Expedition, collected by Mr. J. Stanley Gardiner, M.A. Trans. Linn. Soc. Lond. Ser. 2 Bot. 8:105-142.

Womersley, H. B. S. \& Wollaston, E. M. 1998. Tribe Spongoclonieae Schmitz 1889: 450. In Womersley, H. B. S. (Ed.) The Marine Benthic Flora of Southern Australia, Part IIIC, Ceramiaceae, Dasyaceae. State Herbarium of South Australia, Department for Environment, Heritage and Aboriginal Affairs, Government of South Australia, Adelaide, pp. 286-300.

Won, B. Y., Cho, T. O. \& Fredericq, S. 2009. Morphological and molecular characterization of species of the genus Centroceras (Ceramiaceae, Ceramiales), including two new species. J. Phycol. 45:227-250.

Wynne, M. J. 1984. The correct name for the type of Hypoglossum Kützing (Delesseriaceae, Rhodophyta). Taxon 33:85-87.

Wynne, M. J. 1985. Evidence for the transfer of Cyclospora curtissiae J. Agardh to Carpoblepharis (Ceramiaceae, Rhodophyta). Phycologia 24:49-54. 
Wynne, M. J. 1986. A checklist of benthic marine algae of the tropical and subtropical western Atlantic. Can. J. Bot. 64:2239-2281.

Wynne, M. J. 1989. The re-instatement of Hydropuntia Montagne (Gracilariaceae, Rhodophyta). Taxon 38:476-479.

Wynne, M. J. 1994. The description of Hypoglossum subsimplex sp. nov. (Delesseriaceae, Rhodophyta) from the Florida Keys, Gulf of Mexico. Cryptogam. Algol. 15:253262.

Wynne, M. J. 1995. Benthic marine algae from the Seychelles collected during the R/V Te Vega Indian Ocean Expedition. Contrib. Univ. Mich. Herb. 20:261-346.

Wynne, M. J. 1997. Nitophyllum adhaerens sp. nov. (Delesseriaceae, Rhodophyta) from the Caribbean and Bermuda. Cryptogam. Algol. 18:211-221.

Wynne, M. J. 1998. A checklist of benthic marine algae of the tropical and subtropical western Atlantic: first revision. Nova Hedwigia Beih. 116:1-155.

Wynne, M. J. 2005. A checklist of benthic marine algae of the tropical and subtropical western Atlantic: second revision. Nova Hedwigia Beih. 129:1-152.

Wynne, M. J. 2009a ['2008']. First report of the brown algal Padina glabra (Ochrophyta: Dictyotales) from the coast of Texas and the Gulf of Mexico. Tex. J. Sci. 60:227-232.

Wynne, M. J. 2009b ['2008']. A checklist of benthic marine algae of the coast of Texas. Gulf Mex. Sci. 2008:64-87.

Wynne, M. J. 2011. A checklist of benthic marine algae of the tropical and subtropical western Atlantic: third revision. Nova Hedwigia Beih. 140:1-166.

Wynne, M. J. \& Ballantine, D. L. 1986. The genus Hypoglossum Kützing (Delesseriaceae, Rhodophyta) in the tropical western Atlantic, including H. anomalum sp. nov. J. Phycol. 22:185-193.

Wynne, M. J. \& Ballantine, D. L. 1991. Laurencia iridescens sp. nov. (Rhodomelaceae, Ceramiales) from the Caribbean Sea. Phycologia 30:394-401.

Wynne, M. J. \& De Clerck, O. 1999. First reports of Padina antillarum and P. glabra (Phaeophyta-Dictyotaceae) from Florida, with a key to the western Atlantic species of the genus. Caribb. J. Sci. 35:286-295.

Wynne, M. J. \& Edwards, P. 1970. Polysiphonia boldii sp. nov. from Texas. Phycologia 9:11-16.

Wynne, M. J. \& Huisman, J. M. 1998. First report of Yamadaella caenomyce (Liagoraceae, Rhodophyta) from the Atlantic Ocean, with descriptive notes and comments on nomenclature. Caribb. J. Sci. 34:280-285.

Wynne, M. J. \& Kraft, G. T. 1985. Hypoglossum caloglossoides sp. nov. (Delesseriaceae, Rhodophyta) from Lord Howe Island, South Pacific. Br. Phycol. J. 20:9-19.

Wynne, M. J. \& Leliaert, F. 2001. Pedobesia simplex (Kützing) comb. nov. (Chlorophyta), a new name for P. lamourouxii and its first report from the Indian Ocean. Cryptogam. Algol. 22:3-14.

Wynne, M. J., Price, I. R. \& Ballantine, D. L. 1989. Distinctions between Hypoglossum barbatum Okamura, H. minimum Yamada and H. simulans sp. nov. (Delesseriaceae, Rhodophyta). Phycologia 28:28-38.

Wynne, M. J. \& Schneider, C. W. 1996. Frikkiella gen. nov. (Delesseriaceae, Rhodophyta) from Bermuda and the Caribbean Sea. Syst. Bot. 21:77-84.

Wysor, B. \& De Clerck, O. 2003. An updated and annotated list of marine brown algae (Phaeophyceae) of the Caribbean coast of the Republic of Panama. Bot. Mar. 46:151160.

Wysor, B. \& Kooistra, W. H. C. F. 2003. An annotated list of marine Chlorophyta from the Caribbean coast of the Republic of Panama. Nova Hedwigia 77:487-523.

Yoneshigue, Y. 1984. Marine flora of Cabo Frio (Brazil). On a new species of Peyssonnelia (Cryptonemials: Rhodophyta). Vie Milieu 34:133-137.

Yoneshigue, Y. 1985. Taxonomie et ecologie des algues marines dans la région de Cabo Frio (Rio de Janeiro, Brésil). Ph.D. dissertation, Thèse présentée à l'Université d'Aix-Marseille II, Faculté des Sciences de Luminy pour obtenir le grade de Docteur d'Etate-Scienes, Marseille Cedex, France, 466 pp.

Yoneshigue-Valentin, Y., Fujii, M. T. \& Gurgel, C. F. D. 2003. Osmundea lata (M. Howe \&W.R. Taylor) comb. nov. (Ceramiales, Rhodophyta) from the Brazilian south-eastern continental shelf. Phycologia 42:301-307.

Yoneshigue, Y. \& Oliveira Filho, E. C. de. 1984. Algae from Cabo Frio upwelling area. 2. Gelidiocolax pustulata (Gelidiaceae, Rhodophyta): an unusual new putative parasitic species. J. Phycol. 20:440-443.

Yoon, H. S., Müller, K. M., Sheath, R. G., Ott, F. D. \& Bhattacharya, D. 2006. Defining the major lineages of red algae (Rhodophyta). J. Phycol. 42:482-492.

Yoshida, T. \& Mikami, H. 1991. Sorella pulchra (Yamada) comb. nov., based on Erythroglossum pulchrum Yamada (Delesseriaceae, Rhodophyta). Jpn. J. Phycol. 39:123129.

Young, D. N. 1981. Taxonomic observations on eastern Pacific Antithamnion species (Rhodophyta: Ceramiaceae) described by E. Y. Dawson. Proc. Biol. Soc. Wash. 94:94100 .

Zechman, F. W., Verbruggen, H., Leliaert, F., Ashworth, M., Buchheim, M. A., Fawley, M. W., Spalding, H., Pueschel, C. M., Buchheim, J. A., Verghese, B. \& Hanisak, M. D. 2010. An unrecognized ancient lineage of green plants persists in deep marine waters. J. Phycol. 46:1288-1295. 